\title{
Neural Cell Adhesion Molecule Modulates Dopaminergic Signaling and Behavior by Regulating Dopamine $\mathrm{D}_{2}$ Receptor Internalization
}

\author{
Mei-Fang Xiao, ${ }^{1}$ Jin-Chong Xu, ${ }^{1}$ Yuliya Tereshchenko, ${ }^{1}$ Daniel Novak, ${ }^{1}$ Melitta Schachner, ${ }^{1,2,3}$ and Ralf Kleene ${ }^{1}$ \\ ${ }^{1}$ Zentrum für Molekulare Neurobiologie, Universitätsklinikum Hamburg-Eppendorf, D-20246 Hamburg, Germany, ${ }^{2}$ Keck Center for Collaborative \\ Neuroscience and Department of Cell Biology and Neuroscience, Rutgers University, Piscataway, New Jersey 08854, and ${ }^{3}$ Center for Neuroscience, \\ Shantou University Medical College, Shantou 515041, China
}

The dopaminergic system plays an important role in the etiology of schizophrenia, and most antipsychotic drugs exert their functions by blocking dopamine $D_{2}$ receptors $\left(D_{2} R s\right)$. Since the signaling strength mediated by $D_{2} R s$ is regulated by internalization and degradation processes, it is crucial to identify molecules that modulate $\mathrm{D}_{2} \mathrm{R}$ localization at the cell surface. Here, we show that the neural cell adhesion molecule (NCAM) promotes $\mathrm{D}_{2} \mathrm{R}$ internalization/desensitization and subsequent degradation via direct interaction with a short peptide in the third intracellular loop of the $\mathrm{D}_{2} \mathrm{R}$. NCAM deficiency in mice leads to increased numbers of $\mathrm{D}_{2} \mathrm{Rs}$ at the cell surface and augmented $\mathrm{D}_{2} \mathrm{R}$ signaling as a result of impaired $\mathrm{D}_{2} \mathrm{R}$ internalization. Furthermore, NCAM-deficient mice show higher sensitivity to the psychostimulant apomorphine and exaggerated activity of dopamine-related locomotor behavior. These results demonstrate that, in addition to its classical function in cell adhesion, NCAM is involved in regulating the trafficking of the neurotransmitter receptor $\mathrm{D}_{2} \mathrm{R}$ as well as receptor-mediated signaling and behavior, thus implicating NCAM as modulator of the dopaminergic system and a potential pharmacological target for dopamine-related neurological and psychiatric disorders.

\section{Introduction}

The dopaminergic system is involved in the regulation of locomotion, cognition, emotional behavior, and endocrine secretion. Aberrant dopaminergic signaling is implicated in several neurological and psychiatric disorders, such as Parkinson's disease, depression, schizophrenia, and drug abuse (Zhou and Palmiter, 1995; Carlsson, 2001; Greengard, 2001; Nestler, 2001). Dopamine (DA) exerts its effects through two classes of dopamine receptors, $D_{1}$-like receptors $\left(D_{1} R\right.$ and $\left.D_{5} R\right)$ and $D_{2}$-like receptors $\left(D_{2} R, D_{3} R\right.$, and $D_{4} R$ ) (Seeman and Van Tol, 1994; Missale et al., 1998; Beaulieu et al., 2005). Increased activity of $D_{2} R$ signaling is believed to play an important role in the pathogenesis of schizophrenia. Schizophrenic patients show increased baseline occupancy of $D_{2}$ Rs by dopamine, and the number of $D_{2} R s$ is elevated in the striatum of schizophrenic brains (Wong et al., 1986; AbiDargham et al., 2000). Major antipsychotic drugs exert their functions by blocking $\mathrm{D}_{2} \mathrm{Rs}$, and the dopamine-releasing drugs

Received Sept. 30, 2009; accepted 0ct. 1, 2009.

We are grateful to the Deutsche Forschungsgemeinschaft for support (Scha185/51-1). We are particularly grateful to Dr. Kim A. Neve for providing the myc- $D_{2} R$-expressing cell line and Dr. David R. Sibley for the vector encoding $D_{2} R$. We thank Eva Kronberg for animal care; Dr. Fabio Morellini, Dr. Iryna Leshchyns'ka, and Achim Dahlmann for mice breeding and genotyping; Jens Lüttjohann for phage display screening; Dr. Harold Cremer for NCAM-deficient mice; Dr. Burkhard Schlosshauer for the $D_{3}$ antibody; Dr. Patricia Maness for the expression vectors pcDNA3NCAM140 and pcDNA3-NCAM180; and Dr. Gabriele Loers and Dr. Edgar Kramer for helpful discussions and comments on this manuscript.

Correspondence should be addressed to Melitta Schachner, Zentrum für Molekulare Neurobiologie, Universitätsklinikum Hamburg-Eppendorf, Martinistrasse 52, D-20246 Hamburg, Germany. E-mail: melitta.schachner@ zmnh.uni-hamburg.de.

DOl:10.1523/JNEUROSCI.4860-09.2009

Copyright $\odot 2009$ Society for Neuroscience $\quad 0270-6474 / 09 / 2914752-12 \$ 15.00 / 0$ worsen emotional symptoms (Creese et al., 1976; Gray and Roth, 2007).

$\mathrm{D}_{2} \mathrm{R}$-mediated signaling is extensively regulated by multiple processes, and endocytosis is a major mechanism of $\mathrm{D}_{2} \mathrm{R}$ signal attenuation. $\mathrm{D}_{2} \mathrm{R}$ internalization occurs through clathrinmediated endocytosis (Paspalas et al., 2006), a common mechanism for protein internalization from the plasma membrane (Mousavi et al., 2004). After endocytosis, internalized $\mathrm{D}_{2} \mathrm{Rs}$ are targeted to lysosomes for degradation; thus, $\mathrm{D}_{2} \mathrm{R}$ responses fail to resensitize after agonist treatment (Bartlett et al., 2005). $\mathrm{D}_{2} \mathrm{R}$ internalization is finely tuned, and impaired internalization has been implicated in schizophrenia (Iizuka et al., 2007). However, apart from the essential role of phosphorylation in $\mathrm{D}_{2} \mathrm{R}$ internalization (Ito et al., 1999; Kabbani et al., 2002; Namkung and Sibley, 2004 ), the specific molecular mechanisms that modulate $\mathrm{D}_{2} \mathrm{R}$ endocytosis have remained poorly understood.

Neural cell adhesion molecule (NCAM) is a glycoprotein highly expressed and first discovered in the nervous system (Edelman, 1985). Three major isoforms are generated by alternative splicing: NCAM180 and NCAM140 are transmembrane proteins, whereas NCAM120 is attached to the plasma membrane via a glycophosphatidyl inositol linkage (Maness and Schachner, 2007). NCAM is widely expressed in midbrain dopaminergic neurons and exerts a regulatory role on the development and survival of dopaminergic neurons via mediating the signaling of the neurotrophic factors, glial cell line-derived neurotrophic factor (GDNF) and brain-derived neurotrophic factor (Hyman et al., 1991; Lin et al., 1993; Levivier et al., 1995; Muller et al., 2000; Chao et al., 2003; Paratcha et al., 2003). Increasing evidence in- 
dicates that NCAM is related to psychiatric and neurodegenerative disorders, such as schizophrenia and bipolar disorders (Brennaman and Maness, 2008). NCAM180-deficient mice show impaired prepulse inhibition of startle (PPI), which is one characteristic of schizophrenic patients (Wood et al., 1998). Transgenic mice expressing the extracellular domain of NCAM show higher basal locomotor activity and enhanced responses to amphetamine, an indirect dopamine agonist, and a deficit in PPI (Pillai-Nair et al., 2005). In addition, schizophrenic patients show reduced polysialylated NCAM levels in hippocampus (Barbeau et al., 1995) and increased soluble NCAM fragments in CSF or in hippocampus and cortex (Lyons et al., 1988; van Kammen et al., 1998; Vawter et al., 1998).

Since both $\mathrm{D}_{2} \mathrm{R}$ and NCAM are associated with schizophrenia, we became interested in a potential functional relationship between $\mathrm{D}_{2} \mathrm{R}$ and NCAM. Here, we show that NCAM plays an important role in the regulation of $\mathrm{D}_{2} \mathrm{R}$-dependent locomotor activity by modulating $\mathrm{D}_{2} \mathrm{R}$ internalization. NCAM deficiency in mice leads to hyperactivity of dopamine-related locomotion because of a disrupted $\mathrm{D}_{2} \mathrm{R}$ internalization process, which in turn results in augmented $\mathrm{D}_{2} \mathrm{R}$ signaling.

\section{Materials and Methods}

\section{Experimental animals}

C57BL/6J mice bred and maintained at the Universitätsklinikum Hamburg-Eppendorf were used for all experiments. NCAM-deficient $\left(\mathrm{NCAM}^{-1-}\right)$ mice (Cremer et al., 1994) kindly provided by $\mathrm{H}$. Cremer (Developmental Biology Institute of Marseille Luminy, Centre National de la Recherche Scientifique/Université de Méditerranée, Marseille, France) have been backcrossed onto the C57BL/6J background for more than eight generations and their age-matched wild-type $\left(\mathrm{NCAM}^{+/+}\right)$ mice were used as controls. In all experiments, 2- to 3-month-old mice were used with the exception of hippocampal cultures, which used 1- to 2-d-old mice. Animals were housed at $25^{\circ} \mathrm{C}$ on a $12 \mathrm{~h}$ light/dark cycle with ad libitum access to food and water.

\section{Antibodies}

NCAM monoclonal $\mathrm{D}_{3}$ antibody (Schlosshauer, 1989) reacting with an epitope encoded by the NCAM180-specific exon 18, monoclonal 5B8 antibody (Dodd et al., 1988) recognizing the intracellular domains (ICDs) of NCAM140 and NCAM180, and polyclonal NCAM antibody $1 \beta 2$ recognizing the extracellular domain of mouse NCAM have been described previously (Niethammer et al., 2002). Monoclonal antibody against $D_{2} R$ and myc were obtained from Santa Cruz Biotechnology. Dopamine and cAMP-regulated phosphoprotein with molecular weight $32 \mathrm{kDa}$ (DARPP32) antibody was purchased from Cell Signaling Technology. Tyrosine hydroxylase $(\mathrm{TH})$ and $\mathrm{D}_{1} \mathrm{R}$ antibodies were from Millipore. Antibodies against phospho-TH Ser40 or phospho-DARPP32 Thr34 were obtained from AbD Serotec. Mouse antibody against pentaHis was from QIAGEN. Goat antibody against glutathione $S$-transferase (GST) was from GE Healthcare. All horseradish peroxidase (HRP)coupled secondary antibodies and $\mathrm{Cy} 2, \mathrm{Cy} 3$, and Cy5-coupled secondary antibodies were obtained from Jackson ImmunoResearch Laboratories. Neutravidin-HRP was from Sigma-Aldrich.

\section{DNA constructs}

Rat pcDNA3-NCAM140 and rat pcDNA3-NCAM180 were kind gifts from P. Maness (University of North Carolina, Chapel Hill, NC). Exon 18, NCAM140-ICD, N-terminal truncated NCAM140-ICD (140ICD $\Delta \mathrm{N}$, lacking amino acids 730-772), and NCAM180-ICD in pQE30 were used to generate various His-tagged NCAM fragments. The fulllength rat $\mathrm{D}_{2} \mathrm{R}$ cDNA cloned in pcDNA3 was kindly provided by $\mathrm{D}$. R. Sibley (National Institute of Neurological Disorders and Stroke-National Institutes of Health, Bethesda, MD). IC3-D ${ }_{2} \mathrm{R}$ was subcloned into pGEX-4T-2 to generate the GST-tagged protein. Mutation of IC3- $\mathrm{D}_{2} \mathrm{R}$ (S311C), which is associated with schizophrenia (Itokawa et al., 1993), was generated by using QuickChange II XL-Site Directed Mutagenesis kit (Strat- agene). To create the IC3- $\mathrm{D}_{2} \mathrm{R}$ (S311C) mutant, the sense primer $5^{\prime}$-CTC ACT CTC CCT GAT CCA TGC CAC CAC GGC CTA CAT AGC- $3^{\prime}$ and the antisense primer $5^{\prime}$-GCT ATG TAG GCC GTG GTG GCA TGG ATC AGG GAG AGT GAG-3' were used (sequence differences to wild-type $\mathrm{D}_{2} \mathrm{R}$ are given in bold letters). All DNA constructs were generated by PCR and sequences were verified.

\section{Cell culture and transfection}

Cultures of hippocampal neurons were prepared from 1- to 2-d-old C57BL/6J mice. Hippocampi were isolated, digested in trypsin (SigmaAldrich) plus DNase (Sigma-Aldrich), and triturated in DNase with firepolished glass pipettes. Cells were then centrifuged, resuspended, and plated in Neurobasal A medium (Invitrogen) supplemented with B-27 (Invitrogen), $5 \mu \mathrm{g} / \mathrm{ml}$ gentamycin, $1 \mathrm{~mm}$ L-glutamine, $5 \mu \mathrm{M}$ cytosine $\beta$-D-arabinofuranoside, and $12.5 \mathrm{ng} / \mathrm{ml}$ fibroblast growth factor (PeproTech) on coverslips coated with $100 \mu \mathrm{g} / \mathrm{ml}$ poly-L-lysine (Sigma-Aldrich). One-half of the medium was replaced with fresh medium every $2 \mathrm{~d}$.

Stably myc-D ${ }_{2}$ R-expressing HEK293 cells (Liu et al., 2007), kindly provided by K. A. Neve (Department of Behavioral Neuroscience, Oregon Health \& Science University, Portland, OR), were maintained in DMEM supplemented with $10 \%$ fetal calf serum and $2 \mu \mathrm{g} / \mathrm{ml}$ puromycin (Sigma-Aldrich). HEK293 cells were transiently transfected with pcDNA3-NCAM180 by FuGENE 6 transfection reagent (Roche Diagnostics) according to the protocol of the manufacturer.

For analysis of $\mathrm{D}_{2} \mathrm{R}$ degradation, HEK293- $\mathrm{D}_{2} \mathrm{R}$ cells transfected with NCAM were stimulated with $10 \mu \mathrm{M}$ dopamine (Sigma-Aldrich) at $37^{\circ} \mathrm{C}$ during different time periods in the presence of $10 \mu \mathrm{g} / \mathrm{ml}$ protein synthesis inhibitor cycloheximide (Tocris Bioscience). Cells were then lysed with RIPA buffer (50 mM Tris- $\mathrm{HCl}, 150 \mathrm{~mm} \mathrm{NaCl}, 1 \mathrm{mM} \mathrm{Na}_{4} \mathrm{P}_{2} \mathrm{O}_{7}, 1 \mathrm{~mm}$ $\mathrm{NaF}, 1$ mм EDTA, $2 \mathrm{~mm} \mathrm{Na}_{3} \mathrm{VO}_{4}$, 1 mм PMSF, $1 \% \mathrm{NP}-40$ plus complete EDTA-free protease inhibitor mixture, $\mathrm{pH} 7.5$ ) for $30 \mathrm{~min}$ at $4^{\circ} \mathrm{C}$ and subjected to SDS-PAGE and Western blot analysis.

\section{Phage display}

A phage library (New England Biolabs) displaying $10^{8}-10^{10}$ random 12-mer peptides at the pili of M13-like phage particles in fusion with the $\mathrm{N}$ terminus of the pVIII major coat protein was used. All in vitro selection steps were performed according to the instruction manual, version 2.0, of Ph.D.-12 Phage Display Peptide Library kit (New England Biolabs).

\section{Western blot analysis}

For analysis of phosphorylated proteins, brains from 2- to 3-month-old mice were homogenized in 1\% SDS and immediately boiled for $10 \mathrm{~min}$. Protein extracts were separated by $10 \%$ SDS-PAGE and transferred onto nitrocellulose membrane (Protran; Whatman Schleicher and Schuell). For immunoblotting, membranes were blocked with 5\% nonfat dry milk powder in $\mathrm{PBS}, \mathrm{pH} 7.4$, and incubated overnight at $4^{\circ} \mathrm{C}$ with primary antibodies. After washes with PBST (PBS with $0.1 \%$ Tween 20), membranes were incubated with appropriate HRP-conjugated secondary antibodies for $1 \mathrm{~h}$ at room temperature. For detection of biotinylated proteins, membranes were incubated with streptavidin coupled to HRP. After extensive washes, immunoreactive or streptavidin-reactive bands were visualized using either the enhanced chemiluminescent substrate (ECL) or the chemiluminescent substrate with extended duration (Pierce) on x-ray films (Kodak Biomax-ML; Sigma-Aldrich). Band intensities were densitometrically quantified using the image software TINA 2.09.

\section{GST pull-down assay}

GST-tagged IC3- $\mathrm{D}_{2} \mathrm{R}$ (GST-IC3-D 2 R) was expressed in Escherichia coli and purified using glutathione agarose beads (Sigma-Aldrich) according to the manufacturer's instructions. NCAM-ICDs and various fragments of NCAM140-ICD or NCAM180-ICD were expressed in E. coli and captured by Ni-nitrilotriacetic acid (NTA) agarose beads. Equal amounts of GST proteins were incubated with His-tagged NCAM-ICDs in PBS containing $1 \% \mathrm{BSA}$ at $4^{\circ} \mathrm{C}$ overnight with gentle rotation. Afterward, glutathione agarose beads were added and incubated at $4^{\circ} \mathrm{C}$ for $8 \mathrm{~h}$ under constant agitation, followed by extensive washes with PBS containing $1 \%$ 
NP-40. The pulled down proteins were subjected to SDS-PAGE and Western blot analysis.

\section{Immunoprecipitation}

Brains from 2- to 3-month-old C57BL/6J mice were homogenized in 50 mm Tris-HCl, pH 7.5, $1 \mathrm{~mm} \mathrm{CaCl}_{2}, 1 \mathrm{~mm} \mathrm{MgCl}_{2}$ and $1 \mathrm{~mm} \mathrm{NaHCO}_{3}$ plus complete EDTA-free protease inhibitor mixture (Roche Diagnostics). Brain protein extracts were generated by lysing brain homogenates with RIPA buffer for $1 \mathrm{~h}$ at $4^{\circ} \mathrm{C}$. Protein extracts of HEK293 cells were generated from stably myc- $\mathrm{D}_{2} \mathrm{R}$-expressing HEK293 cells transiently transfected with pcDNA3-NCAM. Two days later, cells were rinsed and lysed in RIPA buffer, followed by additional disruption with repeated aspiration through a 25 gauge needle. After centrifugation at $700 \times g$ for $10 \mathrm{~min}$ at $4^{\circ} \mathrm{C}$, the resulting supernatant was taken as cell lysate for immunoprecipitation.

Protein extracts were cleared with protein A/G-agarose beads (Santa Cruz Biotechnology) for $3 \mathrm{~h}$ at $4^{\circ} \mathrm{C}$, and then incubated with anti- $\mathrm{D}_{2} \mathrm{R}$ antibody or control IgG overnight at $4^{\circ} \mathrm{C}$ with gentle rotation. Protein A/G-agarose was added to capture immunocomplexes for $6 \mathrm{~h}$ at $4^{\circ} \mathrm{C}$ under constant agitation. After extensive washes with RIPA buffer, immunoprecipitated proteins were eluted from agarose beads by $2 \times$ SDS sample buffer (125 mm Tris- $\mathrm{HCl}, 4 \%$ SDS, $30 \%$ glycerol, $10 \%$ $\beta$-mercaptoethanol, and $0.00625 \%$ bromophenol blue, $\mathrm{pH}$ 6.8).

\section{Biochemical cross-linking}

ICDs of NCAM180, NCAM140, or close homolog of L1 (CHL1) were coupled to the trifunctional cross-linker Sulfo-SBED (Pierce) by incubation for $1 \mathrm{~h}$ at room temperature in the dark. Unbound cross-linker was removed by overnight dialysis against $\mathrm{PBS}$ at $4^{\circ} \mathrm{C}$. Brains from 2- to 3-month-old C57BL/6J mice were homogenized at $4^{\circ} \mathrm{C}$ in lysis buffer $\mathrm{P}+$, which contains PBS plus $1 \mathrm{~mm} \mathrm{MgCl}, 1 \mathrm{~mm} \mathrm{MnCl} 2,1 \mathrm{~mm}$ EDTA, 1 mM NaF, $0.5 \mathrm{~mm} \mathrm{Na}_{3} \mathrm{VO}_{4}, 0.5 \mathrm{~mm} \mathrm{H}_{2} \mathrm{O}_{2}, 1 \mu \mathrm{M}$ okadaic acid, and complete EDTA-free protease inhibitor mixture, or lysis buffer $\mathrm{P}-$, which contains PBS plus protein kinase C inhibitor peptide (Sigma-Aldrich) and complete EDTA-free protease inhibitor mixture. Brain homogenates were added to the ICD-cross-linker baits and incubated for $1 \mathrm{~h}$ at room temperature, followed by photoactivation under ultraviolet (UV) light $(365 \mathrm{~nm})$. Potential interaction partners bound to ICD-cross-linker baits were isolated by Ni-NTA beads (QIAGEN), followed by streptavidin beads (Pierce). After extensive washes, precipitated proteins were separated by SDS-PAGE and subjected to Western blot analysis.

\section{Preparation of subcellular fractions}

Mouse brains were homogenized in HOMO buffer ( $5 \mathrm{~mm}$ Tris- $\mathrm{HCl}, 0.32 \mathrm{M}$ sucrose, $1 \mathrm{~mm} \mathrm{MgCl}_{2}, 1 \mathrm{mM} \mathrm{CaCl}_{2}, 1 \mathrm{~mm} \mathrm{NaHCO}$ plus complete EDTAfree protease inhibitor mixture, $\mathrm{pH}$ 7.5) and centrifuged at $1000 \times \mathrm{g}$ for $10 \mathrm{~min}$ at $4^{\circ} \mathrm{C}$ to pellet nuclei and mitochondria. The resulting supernatant was centrifuged at $17,000 \times g$ for $20 \mathrm{~min}$ at $4^{\circ} \mathrm{C}$.

Isolation of synaptosomes. The $17,000 \times g$ pellet was resuspended in HOMO buffer and loaded onto a discontinuous sucrose gradient, which consisted of $0.8,1.0$, and $1.2 \mathrm{M}$ sucrose from the top to the bottom. After centrifugation at $100,000 \times g$ for $1 \mathrm{~h}$ at $4^{\circ} \mathrm{C}$, the interphase materials between 1.0 and $1.2 \mathrm{M}$ sucrose, which contains synaptosomes, were collected and pelleted by centrifugation.

Isolation of plasma membranes. The $17,000 \times g$ pellet was subjected to a hypotonic shock by adding 9 vol of ice-cold $\mathrm{H}_{2} \mathrm{O}$ plus complete EDTAfree protease inhibitor mixture, and rapidly adjusted to $5 \mathrm{~mm}$ Tris- $\mathrm{HCl}$ by adding $1 \mathrm{~m}$ Tris- $\mathrm{HCl}, \mathrm{pH}$ 7.5. After centrifugation at $25,000 \times g$ for 20 min at $4^{\circ} \mathrm{C}$, the pellet fraction containing lysed membrane was resuspended in HOMO buffer and loaded onto the discontinuous sucrose gradient, which consisted of $0.8,1.0$, and $1.2 \mathrm{M}$ sucrose from the top to the bottom. After centrifugation at $150,000 \times g$ for $2 \mathrm{~h}$ at $4^{\circ} \mathrm{C}$, the interphase materials between 1.0 and $1.2 \mathrm{~m}$ sucrose, which contains plasma membranes, were collected and pelleted by centrifugation.

Isolation of endosomes. The $17,000 \times g$ supernatant was collected and centrifuged at $100,000 \times g$ for $1 \mathrm{~h}$ at $4^{\circ} \mathrm{C}$. The pellet was resuspended in $2 \mathrm{M}$ sucrose gradient solution, and a sucrose gradient containing $0.25,0.8$, $1.15,1.3 \mathrm{M}$ of sucrose was loaded on the top of $2 \mathrm{M}$ samples. After centrifugation at $100,000 \times g$ for $2 \mathrm{~h}$ at $4^{\circ} \mathrm{C}$, the interphase fraction between 0.8 and $1.15 \mathrm{~m}$ sucrose, which contains endosomes, was collected, and proteins were precipitated by methanol-chloroform.

Isolation of lysosomes. Lysosomes were prepared by a discontinuous OptiPrep gradient using the lysosome isolation kit (Sigma-Aldrich). Fractions were collected at the interphases of the OptiPrep gradient and assayed for the lysosomal marker protein, Lamp (lysosome-associated membrane protein). The fraction at the interphase between 8 and $12 \%$ of the OptiPrep gradient was taken as lysosomes.

\section{Cell surface biotinylation}

A confluent monolayer of HEK293-D 2 R cells transiently transfected with $\mathrm{NCAM}$ was washed twice with ice-cold PBS containing $2 \mathrm{mM} \mathrm{MgCl}_{2}$ and $0.5 \mathrm{mM} \mathrm{CaCl}_{2}\left(\mathrm{PBS}^{2+}\right)$, and incubated with $0.5 \mathrm{mg} / \mathrm{ml}$ Sulfo-NHS-LCbiotin (Pierce) for $10 \mathrm{~min}$ at $4^{\circ} \mathrm{C}$. Excess biotin was quenched by incubating cells with $20 \mathrm{~mm}$ glycine for $5 \mathrm{~min}$ at $4^{\circ} \mathrm{C}$. Cells were rinsed twice with $\mathrm{PBS}^{2+}$ and lysed with RIPA buffer for $30 \mathrm{~min}$ at $4^{\circ} \mathrm{C}$. After centrifugation at $700 \times g$ for $10 \mathrm{~min}$ at $4^{\circ} \mathrm{C}$, the supernatant was taken as cell lysates and incubated with streptavidin beads at $4^{\circ} \mathrm{C}$ overnight under constant agitation. After extensive washes with RIPA buffer, precipitated biotinylated proteins were eluted from beads with $2 \times$ SDS sample buffer and subjected to Western blot analysis.

\section{Antibody-feeding immunocytochemistry}

Antibody-feeding immunocytochemistry was performed according to the protocol from Bartlett et al. (2005). Live HEK293-D 2 cells transfected with NCAM were incubated with monoclonal antibody against myc for $5 \mathrm{~min}$ at $37^{\circ} \mathrm{C}$ in a $\mathrm{CO}_{2}$ incubator, washed, and stimulated with dopamine $\left(10 \mu \mathrm{M} ; 60 \mathrm{~min} ; 37^{\circ} \mathrm{C}\right)$. Cells were fixed with $2 \%$ formaldehyde for $5 \mathrm{~min}$ and blocked with 5\% nonimmune goat serum for $30 \mathrm{~min}$ at room temperature before application of $\mathrm{Cy} 3$-conjugated secondary antibody to label cell surface $\mathrm{D}_{2}$ Rs. Internalized $\mathrm{D}_{2}$ Rs were detected by Cy5-conjugated secondary antibody after permeabilizing cells with $0.2 \%$ Triton X-100. Polyclonal antibody against NCAM was applied and incubated overnight at $4^{\circ} \mathrm{C}$, followed by incubation with $\mathrm{Cy} 2$-conjugated secondary antibody after washes.

Confocal images were acquired using a Leica confocal microscope (Leica SP2; Leica Microsystems). For quantification of internalization, the confocal settings for image acquisition were maintained for all cells. Image stacks were flattened into a single image by a maximum projection and analyzed with ImageJ. Surface and internal $\mathrm{D}_{2} \mathrm{R}$ fluorescence intensities were measured as the integrated pixel intensities in the red and blue channels, respectively. Total $\mathrm{D}_{2} \mathrm{R}$ fluorescence was determined as the sum of the surface (red) and the internal (blue) fluorescence intensities. For each cell, the internalization index was defined as the ratio of the internalized fluorescence intensity to the total fluorescence intensity.

\section{Immunocytochemistry}

Cells were fixed in $4 \%$ ice-cold formaldehyde and $4 \%$ sucrose for $15 \mathrm{~min}$, and blocked in 5\% nonimmune goat serum containing $0.2 \%$ Triton $\mathrm{X}-100$ for $30 \mathrm{~min}$ at room temperature. Cells were then incubated with primary antibodies overnight at $4^{\circ} \mathrm{C}$ in a humidified chamber. After several washes with PBS, appropriate secondary antibodies coupled with $\mathrm{Cy} 2$ or $\mathrm{Cy} 3$ were applied and incubated for $1 \mathrm{~h}$ at room temperature in the dark. After extensive washes, nuclei were stained with $4^{\prime}, 6-$ diamidino-2-phenylindole (DAPI) (Sigma-Aldrich), and coverslips were mounted on glass slides with Fluoromount $\mathrm{G}$ (Southern Biotechnology).

\section{Drug administration}

The $\mathrm{D}_{1} \mathrm{R}$-specific antagonist 8-bromo-2,3,4,5-tetrahydro-3-methyl-5phenyl-1 H-3-benzazepin-7-ol hydrobromide (SKF83566) (Tocris Bioscience) or $\mathrm{D}_{2} \mathrm{R}$-specific antagonist raclopride (Sigma-Aldrich) were dissolved in saline and injected intraperitoneally before behavioral testing. To investigate the effect of dopamine receptor agonists in dopaminedepleted mice, a combination of reserpine $(5 \mathrm{mg} / \mathrm{kg}$, i.p.; 20 h before the test; Sigma-Aldrich) and methyl-DL-tyrosine ( $250 \mathrm{mg} / \mathrm{kg}$, i.p.; $1 \mathrm{~h}$ before the test; Sigma-Aldrich) were applied to deplete dopamine in mice (Gainetdinov et al., 2003), followed by administration of the $D_{1} R / D_{2} R$ agonist apomorphine (1 mg/kg, s.c.; Sigma-Aldrich). Reserpine, methyl-DL-tyrosine and apomorphine were dissolved in distilled water with drops of glacial 
acetic acid, hydrochloric acid, or $0.1 \%$ ascorbic acid, respectively. All injections were given in a volume of $0.1 \mathrm{ml} / 30 \mathrm{~g}$ of body weight.

\section{Measurement of locomotor activity}

Locomotion was evaluated in the open field as described previously (Law et al., 2003). The open field consisted of a wooden box $(50 \times 50 \times 40 \mathrm{~cm})$ laminated with rough, matted, light-gray resin and illuminated by a white bulb (100 lux). After drug administration, mice were gently introduced into a cylinder placed at the corner of the box for $5 \mathrm{~s}$. As the cylinder was lifted, mice could move freely in the arena for a duration of $30 \mathrm{~min}$. Locomotor activity was measured at $5 \mathrm{~min}$ intervals and cumulative counts were taken for data analysis with the software EthoVision (Noldus).

\section{Statistical analysis}

Values in graphs are presented as mean + SEM. Data were analyzed by unpaired $t$ test. The threshold value for acceptance of differences between group mean values was $5 \%$.

\section{Results}

NCAM interacts with the $D_{2} R$ at amino acids $296-320$ via the $\mathrm{N}$-terminal segment of NCAM-ICD

In search of interaction partners of NCAM-ICD, we performed a phage display screening of a random 12-mer peptide library using NCAM180-ICD as a bait, and obtained a phage expressing an NCAM180-ICD binding peptide that showed similarity to a sequence stretch within the third intracellular domain (IC3) of $\mathrm{D}_{2} \mathrm{R}$ (Fig. 1A). This short stretch comprising amino acids 296-310 is present in the IC $3-\mathrm{D}_{2} \mathrm{R}$. To ascertain the result from phage display screening, pull-down experiments were performed by using recombinant NCAM180-ICD and GST-IC3-D 2 R. NCAM180ICD was pulled down by GST-IC3- $\mathrm{D}_{2} \mathrm{R}$ in a concentrationdependent manner (Fig. $1 B$ ). No such pull down of NCAM180-ICD was observed when NCAM180-ICD was incubated with the GST control (Fig. $1 B$ ).

Additional pull-down assays were performed to clarify the binding sites on NCAM and $\mathrm{D}_{2} \mathrm{R}$ that could mediate their interaction. NCAM180-ICD differs from NCAM140-ICD by the presence of additional 261 aa, which are encoded by exon 18 (Fig. 1C). Since both NCAM180-ICD (Fig. $1 B$ ) and NCAM140-ICD (data not shown) interacted with $\mathrm{D}_{2} \mathrm{R}$ in the GST pull-down assays, it was unlikely that NCAM180-specific exon 18 sequences are the binding domain for $\mathrm{D}_{2} \mathrm{R}$. Pull-down assays using the recombinant protein encoding exon 18 of NCAM180 revealed no pull down of exon 18 with GST-IC3-D 2 R (Fig. $1 D$ ), verifying that the exon 18 indeed did not mediate the interaction between NCAM and $\mathrm{D}_{2} \mathrm{R}$. Similarly, recombinant $\mathrm{N}$-terminally truncated NCAM140-ICD lacking amino acids 730-772 (NCAM140ICD $\Delta$ N) (Fig. 1C) did not show pull down with GST-IC3-D 2 either (Fig. $1 D$ ), indicating that the binding region is present in the membrane-proximal terminus of NCAM-ICD. To further narrow down the binding site, two peptides matching the N-terminal sequences of NCAM-ICD (peptide 1, 730-750; peptide 2, 748-765) (Fig. 1C) were applied for competition in the pull-down assay. NCAM peptide 2 showed strong competition with the binding of NCAM-ICD to GST-IC3-D 2 , whereas peptide 1 exhibited no competition (Fig. $1 E$ ). This result indicates that the membrane-proximal part of NCAM-ICD carries the binding site for $\mathrm{D}_{2} \mathrm{R}$.

To confirm the phage display result showing that amino acids 296-310 of $\mathrm{D}_{2} \mathrm{R}$ mediate the binding to NCAM, the $\mathrm{D}_{2} \mathrm{R}$ peptide (296-320) (Fig. $1 F$ ) was used as competitor in the GST pull-down assay. The $\mathrm{D}_{2} \mathrm{R}$ peptide reduced the binding of NCAM180-ICD to IC3- $\mathrm{D}_{2} \mathrm{R}$ in a concentration-dependent manner (Fig. $1 F$ ), indicating that the binding site of $\mathrm{D}_{2} \mathrm{R}$ to NCAM localizes to the
A

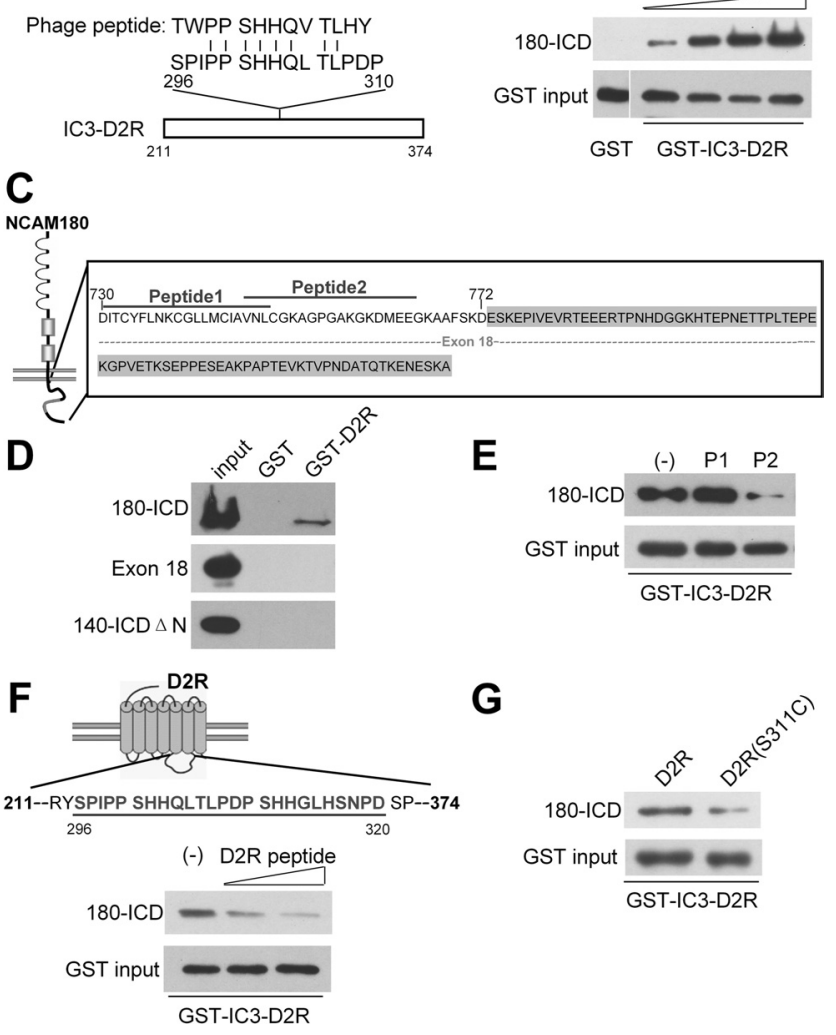

Figure 1. Identification of an interaction of NCAM with $D_{2} R . A$, The sequence of a peptide selected by screening a phage library using the recombinant intracellular domain of NCAM180 (NCAM180-ICD) as a bait shows significant similarity to a sequence in the third intracellular domain of the dopamine $D_{2}$ receptor (IC3- $\left.D_{2} R\right)$. Identical amino acids (|) are shown. Numbers designate amino acid positions. $\boldsymbol{B}$, Increasing amounts of NCAM180-ICD (1-10 $\mu \mathrm{g} / \mathrm{ml})$ were incubated with GST-IC3- $D_{2} R$, followed by pull down with glutathione beads. Incubation of 10 $\mu \mathrm{g} / \mathrm{ml}$ NCAM180-ICD with GST alone was served as control. Pulled down proteins were detected by NCAM antibody $5 B 8$ and GST antibody. C, Schematic representation of NCAM180-ICD structure. The gray-marked sequence highlights N-terminal truncated fragment of NCAM140ICD (140-ICD $\Delta N$, lacking amino acids 730-772). The dashed line indicates exon 18 encoded sequence of NCAM. Numbers designate amino acid positions. D, GST pull-down assay was performed with recombinant His-tagged NCAM180-ICD, exon 18 encoded protein, and NCAM140-ICD $\Delta$ N with GST-IC3-D R or GST as control. Precipitated proteins were detected by anti-Penta His antibody. $\boldsymbol{E}$, GST pull-down assay with NCAM180-ICD and GST-IC3-D 2 R in the presence of NCAM peptide 1 (P1) and peptide 2 (P2). The minus sign ( - ) designates no application of NCAM peptides. $F$, Schematic representation of $D_{2} R$ structure. The line highlights the $D_{2} R$ peptide that shows similarity to the peptide identified by phage library screening, and numbers designate amino acid positions. Pull down was performed with NCAM180-ICD and GST-IC3- $D_{2} R$ in the presence of increasing concentrations of $D_{2} R$ peptide ( 2 and $\left.8 \mu \mathrm{g} / \mathrm{ml}\right)$. The minus sign (-) designates no application of $D_{2} R$ peptide. $G$, GST pull-down assay was performed by incubation NCAM180-ICD with GST-IC3-D R or mutated GST-IC3-D R (S311C).

$\mathrm{D}_{2} \mathrm{R}$ peptide region. These results demonstrate that NCAM interacts with IC3- $\mathrm{D}_{2} \mathrm{R}$ at amino acids 296-320 via an intracellular segment of NCAM close to the transmembrane domain.

The polymorphism of serine to cysteine at the 311 residue of $\mathrm{D}_{2} \mathrm{R}$, which locates within the binding region for NCAM, has been implicated as a risk factor in schizophrenia (Itokawa et al., 1993). To investigate the effect of this mutation on the NCAM/ $\mathrm{D}_{2} \mathrm{R}$ interaction, mutated GST-IC3- $\mathrm{D}_{2} \mathrm{R}$ (S311C) was generated by site-directed mutagenesis and used in the pull-down assay. Compared with wild-type IC3- $\mathrm{D}_{2} \mathrm{R}$, mutated IC3-D 2 R (S311C) showed a $\sim 35 \%$ decrease of the binding to NCAM180-ICD $\left(65.4 \pm 7.3 \%\right.$ in mutated $\mathrm{D}_{2} \mathrm{R}$, when compared with wild-type $\mathrm{D}_{2} \mathrm{R}$, which was set to $100 \% ; n=4 ; p<0.01$ by unpaired $t$ test) 
(Fig. $1 G$ ), indicating that the mutation at 311-serine of $\mathrm{D}_{2} \mathrm{R}$ disrupts the NCAM/ $\mathrm{D}_{2} \mathrm{R}$ interaction, and confirming that this $\mathrm{D}_{2} \mathrm{R}$ sequence stretch mediates the interaction with NCAM.

\section{Cell-biological indications for the $\mathrm{NCAM} / \mathrm{D}_{2} \mathrm{R}$ interaction}

To obtain indications for the NCAM/D $2 \mathrm{R}$ interaction in neural cells, we first examined the subcellular localization of NCAM and $\mathrm{D}_{2} \mathrm{R}$ in cultured hippocampal neurons using immunofluorescence colabeling. NCAM partially colocalized with $\mathrm{D}_{2} \mathrm{R}$ at the cell body and along neurites (Fig. $2 A$ ), suggesting these two proteins associate with each other in neurons.

Next, coimmunoprecipitation experiments were performed using brain homogenate, synaptosomal fractions, or cell lysate from transfected cells. When $\mathrm{D}_{2} \mathrm{R}$ antibody was used for immunoprecipitation, Western blot analysis of immunoprecipitates using an NCAM antibody that recognizes NCAM140 and NCAM180 showed that NCAM180, but not NCAM140, was coimmunoprecipitated from brain homogenate, synaptosomes, and $\mathrm{D}_{2} \mathrm{R}$ transfected cells, whereas no such coimmunoprecipitation was observed with a control antibody (Fig. 2B). This specific coimmunoprecipitation suggests that, in brain tissue and cultured cells, only the NCAM180 isoform interacts with $\mathrm{D}_{2} \mathrm{R}$.

To further characterize the interaction between NCAM and $D_{2} R$, a chemical crosslinking experiment was performed. The trifunctional cross-linker Sulfo-SBED containing a biotin moiety was coupled to the ICDs of NCAM180 and NCAM140, or CHL1 as a control, followed by incubation with brain homogenate. After UV crosslinking, the samples were separated by SDS-PAGE under reducing conditions, which leads to the transfer of the biotin moiety from the cross-linker to the molecules that bound to the ICD-cross-linker conjugates. Biotinylated $\mathrm{D}_{2}$ Rs were detected when NCAM180ICD was used for cross-linking, whereas $\mathrm{D}_{2}$ Rs were not isolated when using NCAM140-ICD or CHL1-ICD (Fig. 2C). In line with results from coimmunoprecipitation experiments, crosslinking revealed that NCAM180, but not NCAM140 interacted with $\mathrm{D}_{2} \mathrm{R}$.

Furthermore, since phosphorylation plays an important role in protein- protein interactions, we performed the crosslinking experiment under condition that favors either phosphorylation or dephosphorylation. We found that the NCAM/ $\mathrm{D}_{2} \mathrm{R}$ interaction was enhanced under phosphorylation conditions compared with dephosphorylation conditions (Fig. 2C).

Together, these observations indicate that NCAM180, but not NCAM140, interacts with $\mathrm{D}_{2} \mathrm{R}$ in cultured neurons and transfected HEK293 cells, brain tissue, and synaptosomes.

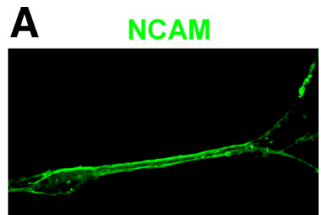

B Input: brain homogenate

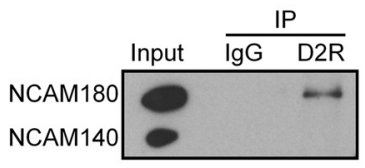

Input: synaptosomes
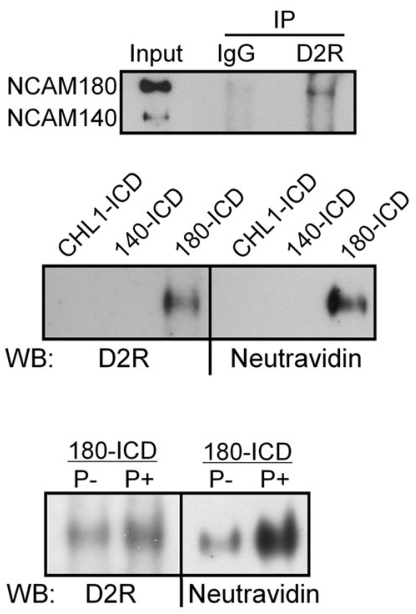

D2R

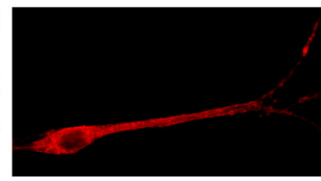

Input: HEK293 Cell lysate

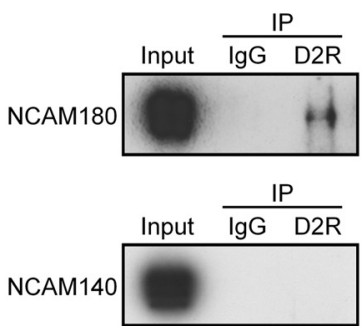

D

\begin{tabular}{lccc} 
& \multicolumn{3}{c}{ IP: D2R } \\
\cline { 2 - 4 } DA $(\min )$ & 0 & 10 & 60 \\
NCAM $\leadsto$ & $\cdots$ & $\ldots$
\end{tabular}

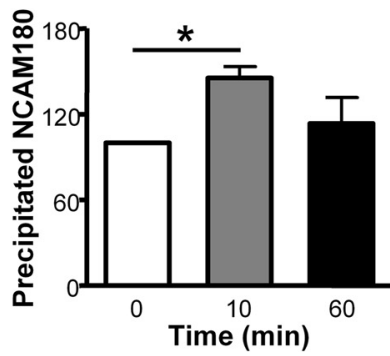

Figure 2. Interaction between NCAM and $D_{2} R$ in cells and tissue. $A$, Cultured hippocampal neurons were subjected to immunostaining with NCAM antibody and $D_{2}$ R antibody; nucleus was stained with DAPI. Colocalization of NCAM and $D_{2}$ Rin cell soma and

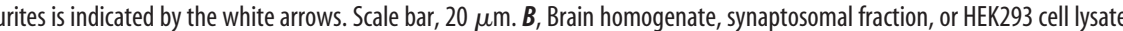
Precipitated proteins were analyzed by Western blot with NCAM antibody 5B8. Coimmunoprecipitation of NCAM180 and D $D_{2}$

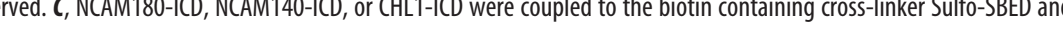
precipitated NCAM was quantified and the amount obtained after 0 min stimulation was set to $100 \%$. Means + SEM are shown. ${ }^{*} p<0.05$ by unpaired $t$ test $(n=3)$.

$\mathrm{NCAM} / \mathrm{D}_{2} \mathrm{R}$ interaction is regulated by dopamine stimulation Agonist-stimulated receptor internalization is a common feature of G-protein-coupled receptors in the regulation of receptor responsiveness to its ligand (Bohm et al., 1997). To investigate whether the formation of the NCAM/ $\mathrm{D}_{2} \mathrm{R}$ complex depends on dopamine stimulation, HEK293 cells transfected with NCAM and $\mathrm{D}_{2} \mathrm{R}$ were stimulated with dopamine followed by immunoprecipitation with $\mathrm{D}_{2} \mathrm{R}$ antibody. Quantitative Western blot analysis of immunoprecipitates showed a significant increase in the levels of NCAM that were coimmunoprecipitated with $\mathrm{D}_{2} \mathrm{R}$ after $10 \mathrm{~min}$ of dopamine stimulation. Sixty minutes after dopamine stimulation, the level of NCAM that was coimmunoprecipitated with $\mathrm{D}_{2} \mathrm{R}$ was comparable with those obtained under nonstimulated conditions (Fig. 2D). This result indicates that the NCAM/D $2 \mathrm{R}$ interaction is enhanced on dopamine stimulation and suggests that NCAM modulates the $\mathrm{D}_{2} \mathrm{R}$ function after dopamine stimulation. 

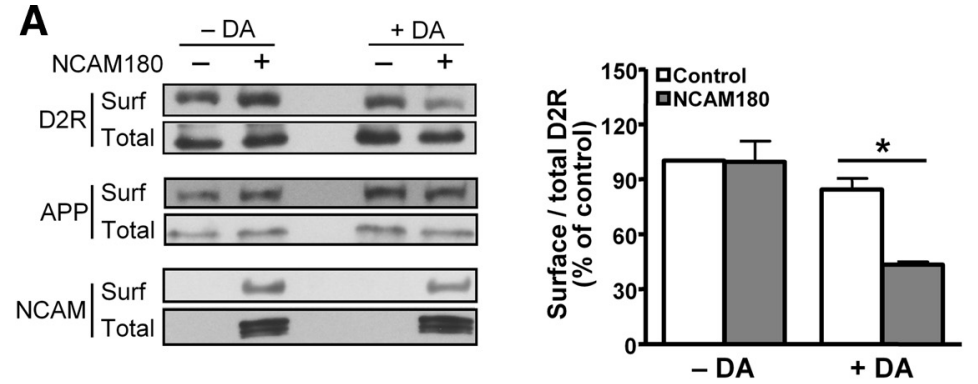

B
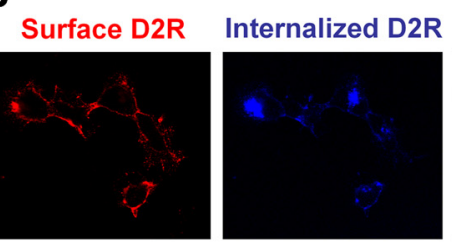

NCAM180
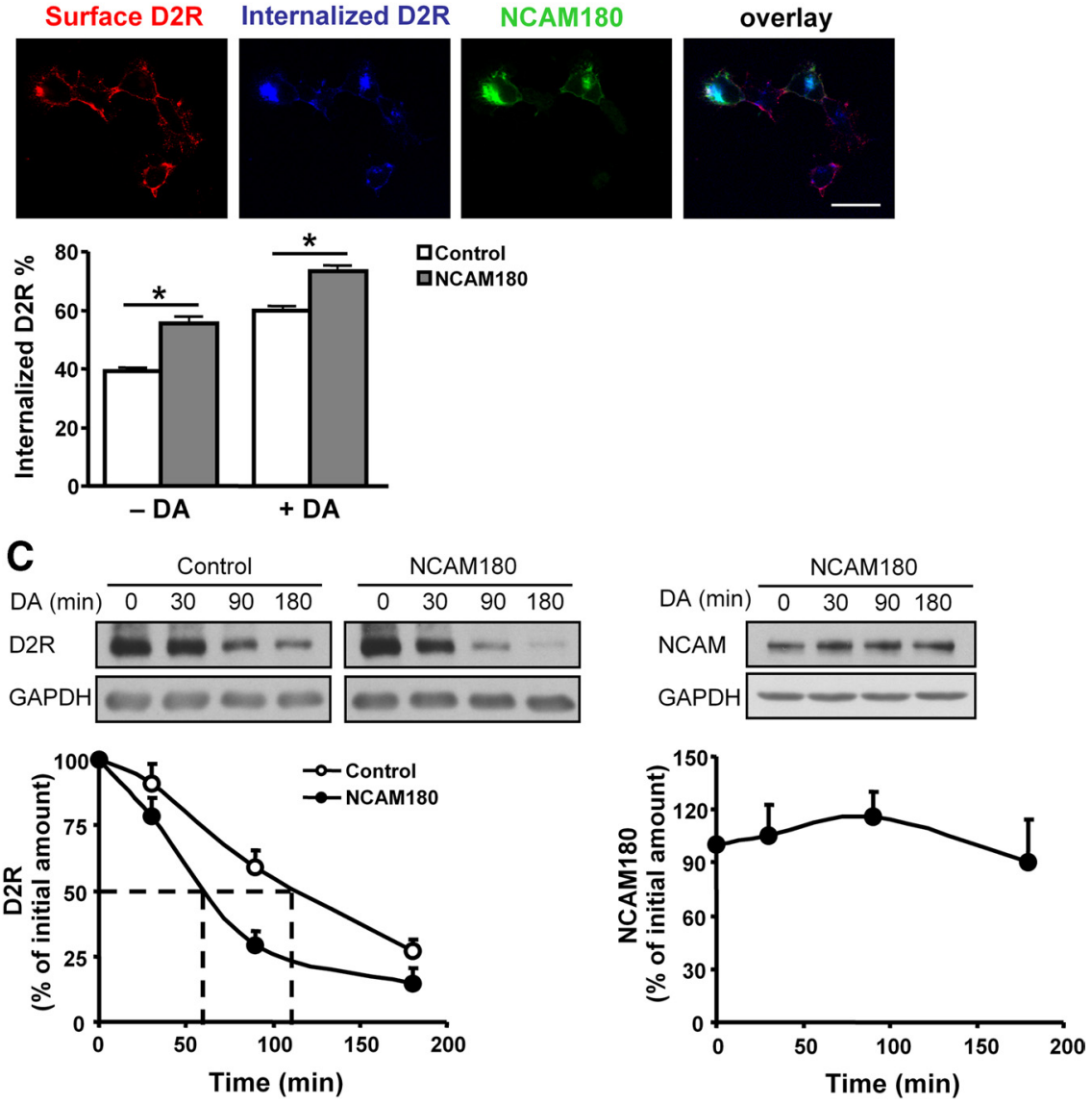

Figure 3. Regulation of $D_{2} R$ trafficking by NCAM. $A$, Myc- $D_{2} R$-expressing HEK293 cells were mock-transfected or transfected with NCAM180. Two days later, cells were stimulated with $10 \mu \mathrm{m}$ DA for $30 \mathrm{~min}$, followed by cell surface biotinylation with Sulfo-NHS-LC-biotin. Biotin-labeled surface proteins (surf) and total proteins (total) were detected by Western blot analysis using antibodies against $D_{2} R, A P P$, or NCAM, respectively. The levels of selected proteins at the cell surface relative to their total levels were determined, with the ratio obtained from the mock-transfected cells in the absence of dopamine being set to $100 \%$. ${ }^{*} p<$ 0.05 by unpaired $t$ test $(n=3)$. $\boldsymbol{B}$, Myc- $D_{2}$ R-expressing HEK293 cells transfected with NCAM180 were subjected to live staining with myc antibody to label cell surface $D_{2} R s$. After treatment with $10 \mu \mathrm{m}$ dopamine, cells were stained with antibodies against $D_{2} R$ before permeabilization (surface $D_{2} R s$ ) and after permeabilization (internalized $D_{2} R s$ ). Percentage of internalized $D_{2} R s$, defined as the ratio of internalized to total fluorescence intensities, was presented as mean + SEM for 50 cells. Results are representative of two independent experiments. ${ }^{*} p<0.05$ by unpaired $t$ test. Scale bar, $25 \mu \mathrm{m}$. C, Myc- $\mathrm{D}_{2} \mathrm{R}$-expressing HEK293 cells transiently transfected with NCAM180 were stimulated with $10 \mu \mathrm{m}$ DA for $0,30,90$, or $180 \mathrm{~min}$ in the presence of $10 \mu \mathrm{g} / \mathrm{ml}$ cycloheximide to block de novo protein synthesis. The levels of $D_{2} R$ and NCAM were evaluated by Western blot analysis with $D_{2} R$ and NCAM antibodies, respectively. Determination of GAPDH levels served as control for loading. The proteins levels obtained by dopamine stimulation for 0 min were set to $100 \%$. The dashed lines indicate $50 \%$ degradation of $D_{2} R$. Means + SEM are shown here $(n=3)$.

NCAM reduces the cell surface localization of $D_{2} R$ and promotes its internalization and degradation

In response to the stimulation of dopamine, $\mathrm{D}_{2}$ Rs undergo internalization in both cultured cells and brain tissue (Itokawa et al., 1996; Sun et al., 2003). To analyze whether NCAM plays a role in $\mathrm{D}_{2} \mathrm{R}$ internalization, we first determined the surface expres- sion of $\mathrm{D}_{2} \mathrm{Rs}$ in dopamine-stimulated HEK293- $\mathrm{D}_{2} \mathrm{R}$ cells by a cell surface biotinylation approach. The levels of surfaceexposed and total $\mathrm{D}_{2} \mathrm{Rs}$ were determined by Western blot using $\mathrm{D}_{2} \mathrm{R}$ antibody. The levels of $\mathrm{D}_{2} \mathrm{Rs}$ at the cell surface in mocktransfected and NCAM180-transfected cells were comparable in the absence of dopamine (Fig. 3A). However, after dopamine stimulation, the amount of $\mathrm{D}_{2} \mathrm{Rs}$ at the cell surface in NCAM180-transfected cells was significantly decreased compared with the mock-transfected cells (Fig. 3A). Quantification of the amount of cell surface $\mathrm{D}_{2}$ Rs normalized to the total amount of $\mathrm{D}_{2}$ Rs revealed a reduction by $\sim 50 \%$. Another transmembrane protein, amyloid precursor protein (APP), remained at a constant level on the cell surface independently on NCAM expression or dopamine stimulation (Fig. 3A). However, no such effect was observed in NCAM140-transfected cells, which showed the same levels of $\mathrm{D}_{2} \mathrm{Rs}$ at the cell surface as obtained in mock-transfected group with dopamine stimulation (data not shown). These results indicate that NCAM180 reduces the cell surface $D_{2} R$ localization on dopamine stimulation. At the same time, NCAM levels at the cell surface were not altered by dopamine stimulation $(84.8 \pm 9.9 \%$ with dopamine stimulation, when the NCAM levels obtained in the absence of dopamine were set to $100 \% ; n=3 ; p>0.05$ by unpaired $t$ test) (Fig. 3A), suggesting that NCAM does not internalize together with $\mathrm{D}_{2}$ Rs on dopamine treatment.

We then investigated whether the decreased cell surface $\mathrm{D}_{2} \mathrm{R}$ localization in NCAM180-expressing cells was attributable to enhanced $\mathrm{D}_{2} \mathrm{R}$ internalization. An antibody-feeding immunocytochemistry approach was taken to label cell surface $\mathrm{D}_{2}$ Rs with antibodies on live cells, followed by exposure to dopamine to trigger internalization of receptor-antibody complexes in live cells. Afterward, remaining surface receptors and internalized receptors were immunostained in the same cell under nonpermeabilization or permeabilization conditions, respectively. Quantification of fluorescence intensity revealed that NCAM180-positive cells, rather than NCAM140-positive cells, showed significantly higher levels of internalized $\mathrm{D}_{2}$ Rs relative to NCAM-negative cells both without and with dopamine stimulation (Fig. 3B) (data for NCAM140 are not shown), indicating that NCAM180, but not NCAM140, promotes the internalization of $\mathrm{D}_{2} \mathrm{R}$ in a dopamineindependent manner.

It has been shown that most internalized $\mathrm{D}_{2}$ Rs are transported to lysosomes for degradation and do not recycle back to the cell 
surface (Bartlett et al., 2005). We therefore examined whether NCAM regulates the degradation of $\mathrm{D}_{2} \mathrm{R}$ by affecting the internalization of $\mathrm{D}_{2} \mathrm{R}$ on dopamine stimulation. HEK293- $\mathrm{D}_{2} \mathrm{R}$ cells were treated with dopamine to stimulate the internalization and degradation of $\mathrm{D}_{2} \mathrm{Rs}$ in the presence of cycloheximide, which blocks protein synthesis (Siegel and Sisler, 1963). Levels of $\mathrm{D}_{2}$ Rs were then determined by quantitative Western blot analysis. Compared with mock-transfected cells, degradation of $\mathrm{D}_{2} \mathrm{Rs}$ was accelerated in NCAM180-transfected, but not in NCAM140-transfected, cells: $50 \%$ of total $\mathrm{D}_{2}$ Rs disappeared after $\sim 60$ min of dopamine stimulation in NCAM180-transfected cells and after $\sim 110$ min in mocktransfected and NCAM140-transfected cells (Fig. 3C) (data for NCAM140 are not shown), respectively. However, NCAM180 was not degraded during the time phase and remained at a constant level on dopamine stimulation (Fig. 3C), indicating that NCAM serves as a "chaperone" molecule for $\mathrm{D}_{2} \mathrm{R}$ internalization and degradation. Together, NCAM180 reduces the level of cell surface $\mathrm{D}_{2} \mathrm{R}$ and promotes its internalization and subsequent degradation.

\section{NCAM deficiency in mice leads to altered subcellular distribution of $\mathrm{D}_{2} \mathrm{R}$}

Since NCAM regulates $\mathrm{D}_{2} \mathrm{R}$ internalization, we asked whether the ablation of NCAM in $\mathrm{NCAM}^{-1-}$ mice alters the internalization of $\mathrm{D}_{2} \mathrm{R}$ in vivo by investigating the subcellular distribution of $\mathrm{D}_{2} \mathrm{R}$ in brains of $\mathrm{NCAM}^{-1-}$ versus $\mathrm{NCAM}^{+/+}$mice. Western blot analysis revealed no difference in total $\mathrm{D}_{2} \mathrm{R}$ expression when comparing the $\mathrm{D}_{2} \mathrm{R}$ levels in brain homogenates or synaptosomes of $\mathrm{NCAM}^{-1-}$ and NCAM ${ }^{+/+}$mice $(108.7 \pm 7.5 \%$ in total brain homogenates and $97.2 \pm 6.9 \%$ in synaptosomes of $\mathrm{NCAM}^{-1-}$ mice, respectively, when compared with $\mathrm{NCAM}^{+/+}$mice, which were set to $100 \% ; n=5 ; p>0.05$ by unpaired $t$ test) (Fig. $4 A$ ). To analyze the cell surface expression of $\mathrm{D}_{2} \mathrm{R}$, plasma membrane fractions were subjected to Western blot analysis. The plasma membrane fraction from $\mathrm{NCAM}^{-/-}$brains showed a twofold $(2.05 \pm 0.13)$ higher amount of $\mathrm{D}_{2}$ Rs relative to that found from $\mathrm{NCAM}^{+/+}$ brains ( $n=5 ; p<0.001$ by unpaired $t$ test) (Fig. $4 B)$, whereas no difference was observed for the $\mathrm{D}_{1} \mathrm{R}(100.2 \pm 10.2 \%$ in $\mathrm{NCAM}^{-1-}$ mice with $\mathrm{D}_{1} \mathrm{R}$ levels in $\mathrm{NCAM}^{+/+}$mice being set to $100 \% ; n=5 ; p>0.05$ by unpaired $t$ test) (Fig. $4 B$ ), indicating that the level of $\mathrm{D}_{2}$ Rs at the plasma membrane is dysregulated in $\mathrm{NCAM}^{-1-}$ mice. Additional analyses of fractions enriched in endosomes, lysosomes, endoplasmic reticulum (ER), and Golgi apparatus were performed. Compared with fractions from NCAM $^{+/+}$brains, a significant reduction in the levels of $D_{2} R s$ was found in endosomal and lysosomal fractions from NCAM $^{-1-}$ brains $(60.1 \pm 7.5 \%$ in endosomes and $60.4 \pm 5.4 \%$ in lysosomes of $\mathrm{NCAM}^{-1-}$ mice, respectively, when compared with $\mathrm{D}_{2} \mathrm{R}$ levels in $\mathrm{NCAM}^{+/+}$mice, which were set to $100 \% ; n=$ $5 ; p<0.01$ by unpaired $t$ test) (Fig. $4 C$ ). No difference was observed with ER or Golgi fractions between the two genotypes (data not shown).

The decrease of $\mathrm{D}_{2} \mathrm{R}$ levels in endosomal and lysosomal fractions and the elevated levels of $\mathrm{D}_{2} \mathrm{R}$ in plasma membrane-derived fractions indicate that NCAM deficiency leads to an abnormal subcellular $\mathrm{D}_{2} \mathrm{R}$ distribution and confirms that NCAM regulates internalization and degradation of $\mathrm{D}_{2} \mathrm{R}$.

\section{NCAM $^{-/-}$mice show augmented $D_{2} R$-mediated signaling}

Since the levels of neurotransmitter receptors at the plasma membrane dictate the strength of receptor responses (Gainetdinov et al., 2003), elevated amounts of $D_{2}$ Rs at the plasma membrane of $\mathrm{NCAM}^{-/-}$brains could indicate an alteration in $\mathrm{D}_{2} \mathrm{R}$-mediated signaling pathways. Activation of the long $\mathrm{D}_{2} \mathrm{R}$ isoform $\left(\mathrm{D}_{2} \mathrm{~L}\right)$, which is predominantly postsynaptic, leads to inhibition of the phosphorylation of DARPP32 at the Thr34 residue, whereas activation of the short $\mathrm{D}_{2} \mathrm{R}$ isoform $\left(\mathrm{D}_{2} \mathrm{~S}\right)$, which is located in presynaptic boutons and functions as an autoreceptor, inhibits the phosphorylation of $\mathrm{TH}$ at the Ser40 residue (Giros et al., 1989; Lindgren et al., 2003) (Fig. 5A). Both pathways were subjected to Western blot analysis with antibodies recognizing the phosphorylated Thr34 of DARPP32 or Ser40 of TH in brain homogenates of $\mathrm{NCAM}^{+/+}$and $\mathrm{NCAM}^{-1-}$ mice. Compared with $\mathrm{NCAM}^{+/+}$brains, the amount of phospho-Thr34DARPP32 was significantly reduced in $\mathrm{NCAM}^{-/-}$mice (Fig. $5 B)$. Quantification of the levels revealed a $\sim 40 \%$ decrease of phospho-Thr34-DARPP32 in $\mathrm{NCAM}^{-/-}$versus $\mathrm{NCAM}^{+/+}$ mouse brains $\left(61.1 \pm 11.6 \%\right.$ in $\mathrm{NCAM}^{-1-}$ mice, when compared with phospho-Thr34-DARPP32 levels in $\mathrm{NCAM}^{+/+}$mice, which were set to $100 \% ; n=6 ; p<0.05$ by unpaired $t$ test) (Fig. $5 B)$. However, the levels of phospho-Ser40-TH were similar in the two genotypes $\left(94.7 \pm 11.2 \%\right.$ in $\mathrm{NCAM}^{-1-}$ mice, when compared with phospho-Ser40-TH levels in NCAM $^{+/+}$mice, which were set to $100 \% ; n=6 ; p>0.05$ by unpaired $t$ test) (Fig. $5 C$ ). These results indicate that $\mathrm{D}_{2} \mathrm{R}$-mediated signaling transduction is enhanced in the absence of NCAM. Because of the differential localization of $\mathrm{D}_{2} \mathrm{R}$ isoforms and specialized downstream effects mediated by $\mathrm{D}_{2} \mathrm{R}$ isoforms, we would suggest that the ablation of NCAM leads to excessive $\mathrm{D}_{2} \mathrm{R}$ signaling, particularly in postsynaptic spines. 
A

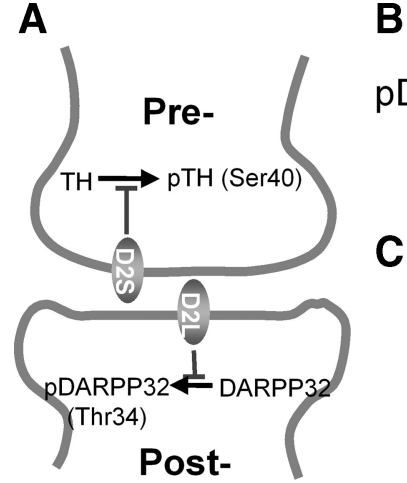

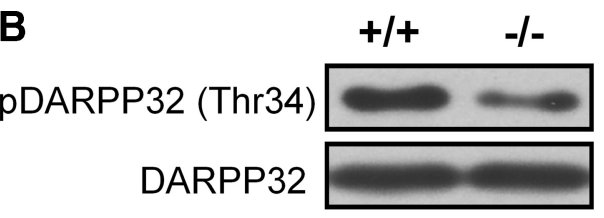

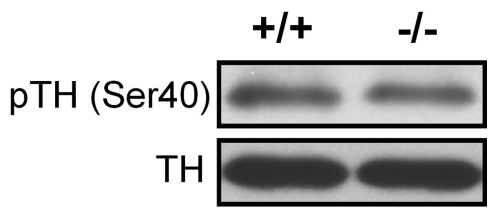

Figure 5. $D_{2} R$-mediated signaling is altered in the absence of NCAM. $A$, Schematic representation of signaling pathways mediated by presynaptic short isoform of $D_{2} R\left(D_{2} S\right)$ and postsynaptic long isoform of $D_{2} R\left(D_{2} L\right)$. The activation of $D_{2} S$ and $D_{2} L$ leads to the inhibition of phosphorylation in TH and DARPP32, respectively. $\boldsymbol{B}, \boldsymbol{C}$, The levels of phosphorylated DARPP32 (pDARPP32) (B) and phosphorylated TH (pTH) $(\boldsymbol{C})$ were analyzed by Western blot and normalized to total DARPP32 and TH levels in brain homogenates of adult $\mathrm{NCAM}^{+/+}$and $\mathrm{NCAM}^{-1-}$ mice.

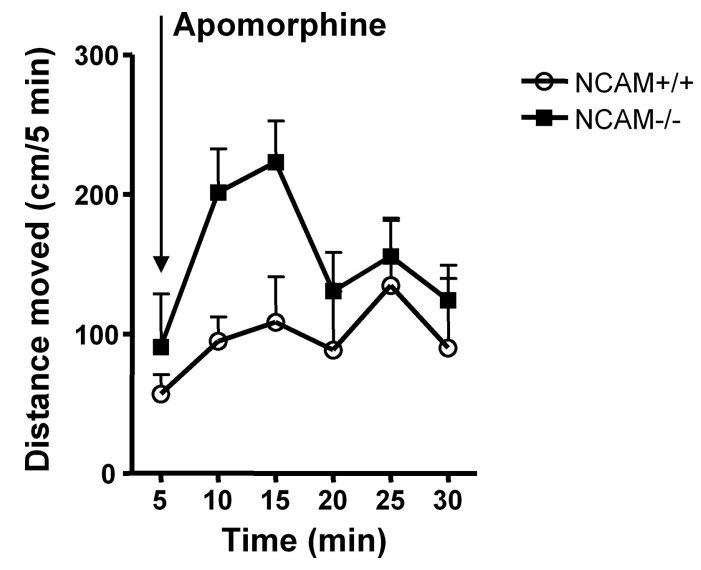

Figure 6. Behavioral responses to dopaminergic agonists are altered in dopamine-depleted NCAM $^{-1-}$ mice. A combination of reserpine $(5 \mathrm{mg} / \mathrm{kg}$, i.p.) and methyl-oL-tyrosine $(250 \mathrm{mg} /$ $\mathrm{kg}$, i.p.) was applied to deplete dopamine in $\mathrm{NCAM}^{+/+}$and $\mathrm{NCAM}^{-1-}$ mice. After injection of the dopamine receptor agonist apomorphine (1 mg/kg, s.c.), dopamine-depleted NCAM ${ }^{+/+}$ and $\mathrm{NCAM}^{-1-}$ mice were placed into the open field, and locomotor activity was immediately monitored for $30 \mathrm{~min}$ at $5 \mathrm{~min}$ intervals. Time course of the effect of apomorphine on the locomotor activity of dopamine-depleted NCAM ${ }^{+/+}$and NCAM ${ }^{-1-}$ mice is shown. Distance moved was counted at 5 min intervals. Mean + SEM values are shown $(n=5)$.

The behavioral response to dopamine receptor activation is enhanced in dopamine-depleted $\mathrm{NCAM}^{-1-}$ mice

Since $\mathrm{D}_{2} \mathrm{R}$-mediated signaling is dysregulated in the absence of NCAM, we investigated whether dopamine-related locomotor activity, which was controlled by nigrostriatal dopaminergic transmission (Hu et al., 1990), was influenced in $\mathrm{NCAM}^{-1-}$ mice. NCAM, known as a signaling receptor of GDNF, plays important roles in the development and survival of midbrain dopaminergic neurons (Lin et al., 1993; Chao et al., 2003; Paratcha et al., 2003). Stereological assessment of $\mathrm{TH}$-positive $\left(\mathrm{TH}^{+}\right)$dopaminergic neurons revealed a $23 \%$ reduction of $\mathrm{TH}^{+}$cells in the substantia nigra of $\mathrm{NCAM}^{-1-}$ mice compared with $\mathrm{NCAM}^{+/+}$mice $\left(6637 \pm 366\right.$ vs $8674 \pm 320 \mathrm{TH}^{+}$cells in the substantial nigra for $\mathrm{NCAM}^{-1-}$ and wild-type mice, respectively; $n=5 ; p<0.05$ by unpaired $t$ test). However, no difference of dopamine levels in total brain and striatum was observed between the two genotypes $(209.0 \pm 5.5$ vs $222.9 \pm 6.4$ in total brain and $1484.0 \pm 217.5$ vs $1500.0 \pm 221.4 \mathrm{nmol}$ of dopamine per gram of proteins in the striatum for $\mathrm{NCAM}^{+/+}$and $\mathrm{NCAM}^{-/-}$mice, respectively; $n=$

$5 ; p>0.05$ by unpaired $t$ test), suggesting that the loss of $\mathrm{TH}^{+}$neurons in the substantia nigra did not lead to the abnormality of dopamine levels in the striatum of $\mathrm{NCAM}^{-1-}$ mice.

Although NCAM deficiency did not cause alterations of dopamine levels in brain tissue, it is possible that the release of dopamine is altered in $\mathrm{NCAM}^{-1-}$ mice. To assess direct sensitivities of dopamine receptors in $\mathrm{NCAM}^{-1-}$ mice, endogenous dopamine was ablated by treatment with reserpine, which depletes intracellular storage of monoamines and thus dopamine, and with methyl-DLtyrosine to inhibit dopamine synthesis. Dopamine-depleted mice were then challenged with the nonselective dopamine receptor agonist apomorphine to assess locomotor responses to dopamine receptor activation. After dopamine depletion, locomotor activity was dramatically reduced both in $\mathrm{NCAM}^{+/+}$and $\mathrm{NCAM}^{-/-}$mice. Administration of apomorphine partially restored the locomotor activity in dopamine-depleted mice. Furthermore, compared with dopaminedepleted $\mathrm{NCAM}^{+/+}$mice, dopamine-depleted $\mathrm{NCAM}^{-/-}$mice showed a markedly enhanced response to apomorphine (924.5 \pm 138.9 vs $572.3 \pm 175.2 \mathrm{~cm} / 30 \mathrm{~min}$ for $\mathrm{NCAM}^{-1-}$ and NCAM $^{+/+}$ mice, respectively; $n=5 ; p<0.05$ by paired $t$ test) (Fig. 6), demonstrating that dopamine receptor responsiveness is enhanced in $\mathrm{NCAM}^{-1-}$ mice.

\section{$\mathrm{NCAM}^{-/-}$mice show hyperactivity of locomotion resulting} from abnormal $D_{2} R$ activity

Since the dopaminergic response was enhanced in dopaminedepleted $\mathrm{NCAM}^{-1-}$ mice, we further investigated which class of dopamine receptor was responsible for this hyperactivity of locomotion in $\mathrm{NCAM}^{-1-}$ mice by using dopamine receptors antagonists. To test the locomotor responses to dopamine receptor antagonists, the $D_{1} R$-specific antagonist SKF83566 or the $D_{2} R$ specific antagonist raclopride were injected into $\mathrm{NCAM}^{-1-}$ mice and $\mathrm{NCAM}^{+/+}$littermates. Immediately after drug administration, mice were placed in open-field boxes and then monitored for locomotor activity. In line with the observation from the dopamine depletion experiment, higher locomotor activity was found in vehicle-treated $\mathrm{NCAM}^{-1-}$ mice when compared with $\mathrm{NCAM}^{+/+}$mice. After treatment with dopamine receptor antagonists, both $\mathrm{D}_{1} \mathrm{R}$ antagonist $\mathrm{SKF} 83566$ and $\mathrm{D}_{2} \mathrm{R}$ antagonist raclopride reduced locomotor activity in $\mathrm{NCAM}^{-1-}$ mice as well as $\mathrm{NCAM}^{+/+}$mice. No significant difference of locomotor activity was observed between genotypes after SKF83566 treatment, and SKF83566 led to comparable and low activity levels of locomotion in both genotypes (Fig. 7). However, after administration of raclopride, locomotor activity was significantly higher in $\mathrm{NCAM}^{-1-}$ mice when compared with $\mathrm{NCAM}^{+/+}$mice (Fig. 7), indicating enhanced activity of $\mathrm{D}_{2} \mathrm{R}$-triggered signaling in $\mathrm{NCAM}^{-1-}$ mice. These observations on locomotor activity strongly suggest that dysregulated $\mathrm{D}_{2} \mathrm{R}$ levels contribute to the hyperactivity of locomotion observed in $\mathrm{NCAM}^{-1-}$ mice.

\section{Discussion}

NCAM180, but not NCAM140, interacts with $D_{2} R$

DRIPs (dopamine receptor interacting proteins), including scaffold and trafficking proteins, signaling molecules, synaptic pro- 
teins, ion channels, and other receptors, appear to be essential in regulating key aspects of receptor signaling and functions (Kabbani and Levenson, 2007). Emerging evidence reveals extensive associations between cell adhesion molecules and neurotransmitter receptors (Stork et al., 1999; Fux et al., 2003; Chih et al., 2005; Kohsaka et al., 2007; Li et al., 2009). Here, we identified the transmembrane cell adhesion molecule NCAM as a novel binding partner of $\mathrm{D}_{2} \mathrm{R}$ and a new modulator of $\mathrm{D}_{2} \mathrm{R}$ signaling. Pull-down assays provide in vitro evidence that the interaction between NCAM and $\mathrm{D}_{2} \mathrm{R}$ is mediated by a membrane-proximal part of NCAM-ICD and the $\mathrm{IC} 3-\mathrm{D}_{2} \mathrm{R}$. The binding regions on NCAM and $D_{2} R$ were narrowed down to amino acids 748-765 and 296-320, respectively.

Although the recombinant proteins NCAM140-ICD and NCAM180-ICD both show binding to the IC3- $\mathrm{D}_{2} \mathrm{R}$ in pull-down assays, immunoprecipitation and chemical cross-linking experiments using brain homogenates clearly demonstrate that only the NCAM180 isoform, which mainly localizes postsynaptically (Persohn et al., 1989), but not NCAM140, interacts with $\mathrm{D}_{2} \mathrm{R}$. Immunoprecipitation using $\mathrm{D}_{2} \mathrm{R}$ expressing cells transfected with either NCAM isoform confirms that NCAM180, but not NCAM140, is associated with $\mathrm{D}_{2} \mathrm{R}$ in a cellular context. Moreover, the interaction of NCAM 180 with $\mathrm{D}_{2} \mathrm{R}$ is regulated by dopamine stimulation and/or phosphorylation of NCAM 180 and/or $\mathrm{D}_{2} \mathrm{R}$, because increased association of NCAM180 with $\mathrm{D}_{2} \mathrm{R}$ is observed by coimmunoprecipitation shortly after dopamine stimulation, or by biochemical cross-linking under phosphorylation conditions. According to these findings, we propose that NCAM180 interacts with $\mathrm{D}_{2} \mathrm{R}$ at postsynaptic sites on dopamine stimulation and that this interaction triggers $\mathrm{D}_{2} \mathrm{R}$ - and NCAM-dependent cellular responses (Fig. 8).

\section{NCAM180 regulates $D_{2} R$}

internalization and trafficking

to endosomal and lysosomal

compartments

G-protein-coupled receptors like $\mathrm{D}_{2} \mathrm{R}$ undergo constitutive and agonist-stimulated internalization, which modulate receptor responsiveness by regulating receptor availability at the cell surface (Rankin et al., 2006). Recent studies suggest a modulatory role of cell adhesion molecules in the trafficking and assembly of presynaptic vesicles and postsynaptic neurotransmitter receptors (Polo-Parada et al., 2001;
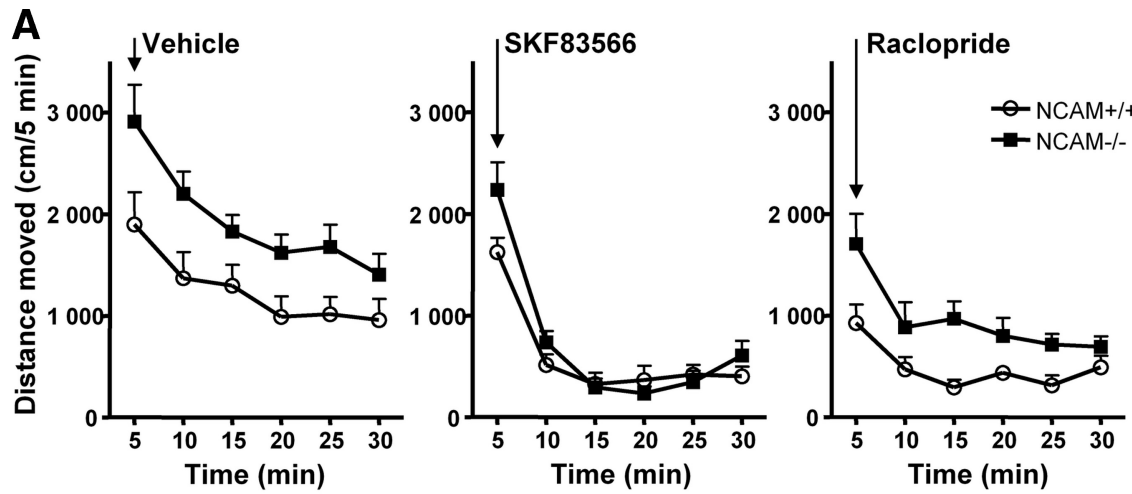

B

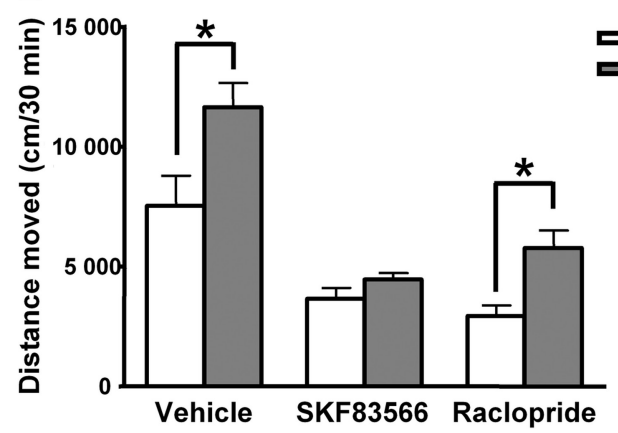

Figure 7. Behavioral responses to dopaminergic antagonists are changed in NCAM ${ }^{-/-}$mice. NCAM ${ }^{+/+}$and NCAM ${ }^{-/-}$mice were placed into the open field after injection of $D_{1} R$-specific antagonist SKF83566, $D_{2} R$-specific antagonist raclopride, or vehicle control ( $0.1 \mathrm{mg} / \mathrm{kg}$, i.p.), and locomotor activity was monitored immediately after injection for $30 \mathrm{~min}$ at $5 \mathrm{~min}$ intervals. $\boldsymbol{A}$, Time course of the effect of dopamine receptor antagonists on the locomotor activity of $\mathrm{NCAM}^{+/+}$and $\mathrm{NCAM}^{-/-}$mice. Distance moved was counted at 5 min intervals. Mean + SEM values are shown $(n=7-9)$. $\boldsymbol{B}$, Total distance moved was measured in $\mathrm{NCAM}^{+/+}$or NCAM ${ }^{-/-}$mice for a period of 30 min after injection of dopamine receptor antagonists. Means + SEM are shown. ${ }^{*} p<0.05$ by unpaired $t$ test $(n=7-9)$.
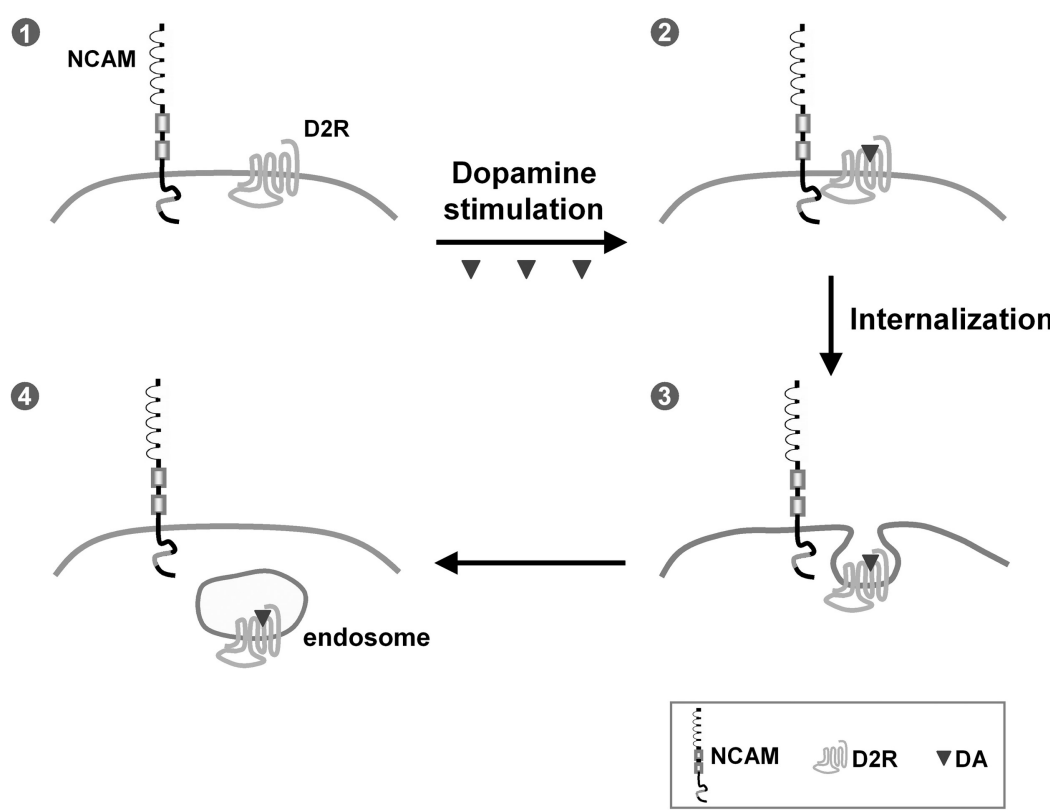

Figure 8. Working model of the modulation of $D_{2} R$ signaling by NCAM. The transmembrane proteins NCAM and $D_{2} R$ are expressed at the cell surface of the postsynaptic terminus (1). On DA stimulation, cell surface NCAM forms a complex with $\mathrm{D}_{2} \mathrm{R}$ by interaction between intracellular domains of the two molecules (2), promotes $D_{2}$ R internalization (3) to endocytic compartments, and leads to the attenuation of $\mathrm{D}_{2} \mathrm{R}$-mediated signal transduction (4). 
Nuriya and Huganir, 2006; Sytnyk et al., 2006; Saglietti et al., 2007). Here, we show by in vitro and in vivo investigations that NCAM regulates $D_{2} R$ internalization and thus affects $D_{2} R$ mediated signaling. Data from cell surface biotinylation using HEK293 cells expressing $\mathrm{D}_{2} \mathrm{R}$ and NCAM180 indicate that NCAM is involved in agonist-induced $\mathrm{D}_{2} \mathrm{R}$ internalization, since enhanced internalization of $\mathrm{D}_{2} \mathrm{R}$ in NCAM-expressing cells was observed only on dopamine stimulation. However, antibodyfeeding internalization assays show that NCAM exerts its function on $\mathrm{D}_{2} \mathrm{R}$ internalization both without and with dopamine stimulation. An explanation for this discrepancy of the results obtained from the two different approaches may be that the application of antibody to live cells in the antibody-feeding assay leads to the clustering of receptors (Diestel et al., 2007), which are likely triggering NCAM and $\mathrm{D}_{2} \mathrm{R}$ internalization even in the absence of dopamine and thus mimic agonist stimulation. Thus, we assume that NCAM mainly functions in agonist-induced $D_{2} R$ internalization. However, we do not exclude the possibility that NCAM might be also involved in constitutive internalization of $\mathrm{D}_{2} \mathrm{R}$. The finding that $\mathrm{D}_{2} \mathrm{R}$ levels, but not $\mathrm{D}_{1} \mathrm{R}$ levels in a plasma membrane-enriched fraction are significantly increased in brains of $\mathrm{NCAM}^{-1-}$ mice confirms that NCAM specifically modulates the internalization of $\mathrm{D}_{2} \mathrm{R}$.

Internalized $\mathrm{D}_{2}$ Rs are targeted to late endosomes and lysosomes for degradation, and, as a consequence, $\mathrm{D}_{2}$ Rs fail to resensitize after agonist stimulation (Bartlett et al., 2005). Here, we show that the levels of $\mathrm{D}_{2} \mathrm{R}$ in endosomal and lysosomal fractions are dramatically reduced in brains from $\mathrm{NCAM}^{-1-}$ mice. Moreover, $\mathrm{D}_{2} \mathrm{R}$ degradation is accelerated in NCAM-transfected cells on dopamine stimulation, indicating that NCAM regulates both $\mathrm{D}_{2} \mathrm{R}$ internalization and subsequent degradation in lysosomes. Additional studies will be needed to analyze the mechanisms by which NCAM regulates the $\mathrm{D}_{2} \mathrm{R}$ endocytosis and degradation.

\section{NCAM modulates dopamine-related signaling and locomotor activity in mice}

Dopamine signaling is extensively modulated by membrane internalization processes, which reduce receptor responsiveness to agonists and protect against receptor overstimulation. Disruption in dopamine receptor internalization leads to dopaminergic supersensitivity, which has been related to several psychiatric disorders (Carlsson, 2001; Nestler, 2001). In the present study, we show that NCAM deficiency leads to a reduction in $\mathrm{D}_{2} \mathrm{R}$ internalization, a corresponding increased cell surface localization of $\mathrm{D}_{2} \mathrm{R}$, and concomitantly enhanced $\mathrm{D}_{2} \mathrm{R}$ signal transduction, which is demonstrated by the reduction in phosphorylation level of the downstream target protein DARPP32, but not of TH. Because of the differential pathways mediated by $\mathrm{D}_{2} \mathrm{R}$ isoforms at presynaptic and postsynaptic terminus (Lindgren et al., 2003), the changes in the phosphorylation level of DARPP32 indicate that the intracellular signal response at postsynaptic terminals mediated by the postsynaptic long isoform of $\mathrm{D}_{2} \mathrm{R}$ is regulated by NCAM. This is consistent with our results, which show that only the postsynaptically localized NCAM180 (Persohn et al., 1989) binds to $D_{2} R$, whereas presynaptic NCAM140 does not interact with $\mathrm{D}_{2} \mathrm{R}$. We thus propose that the interaction and concomitant internalization of NCAM180 and the long isoform of $\mathrm{D}_{2} \mathrm{R}$ regulate the dopaminergic signaling pathways and cellular responses at postsynaptic terminals.

Furthermore, we show that NCAM not only functions as a modulator of $\mathrm{D}_{2} \mathrm{R}$ internalization and $\mathrm{D}_{2} \mathrm{R}$-mediated signaling but also exerts a regulatory effect on dopamine-related locomotor behavior of mice. Dopamine-depleted $\mathrm{NCAM}^{-1-}$ mice show a more pronounced behavioral response to the dopamine receptor agonist apomorphine than dopamine-depleted $\mathrm{NCAM}^{+/+}$ mice, proving that the level of postsynaptic dopamine receptors is dysregulated in the absence of NCAM and that NCAM modulates the dopamine-related locomotion of mice by regulating dopamine receptor sensitivity. Dopamine receptors are classified into $\mathrm{D}_{1}$-like $\left(\mathrm{D}_{1}, \mathrm{D}_{5}\right)$ and $\mathrm{D}_{2}$-like $\left(\mathrm{D}_{2}, \mathrm{D}_{3}, \mathrm{D}_{4}\right)$ based on their physiological and pharmacological properties (Missale et al., 1998). Our investigations on locomotor responses to selective antagonists of dopamine receptors show attenuated inhibitory response to a $\mathrm{D}_{2}$-like receptor antagonist in $\mathrm{NCAM}^{-1-}$ mice in comparison with $\mathrm{NCAM}^{+/+}$mice, whereas no significant difference is seen with a $\mathrm{D}_{1}$-like receptor antagonist. These results demonstrate that both signaling and locomotor behavior related to $\mathrm{D}_{2}$-like, but not $\mathrm{D}_{1}$-like, receptors are modulated by NCAM. However, since there is no known specific $\mathrm{D}_{2} \mathrm{R}$ antagonist and the antagonist we applied is against $\mathrm{D}_{2}$-like receptors, the present data do not rule out the possibility that $\mathrm{D}_{3}$ and $\mathrm{D}_{4}$ receptors might be also responsible for the higher locomotor activity in $\mathrm{NCAM}^{-1-}$ mice.

In vivo, the increase of $\mathrm{D}_{2}$ Rs at the cell surface in the absence of NCAM could be attributable to dysregulation of two pathways. On the one hand, since NCAM directly promotes $\mathrm{D}_{2} \mathrm{R}$ internalization and reduces the amount of $\mathrm{D}_{2} \mathrm{Rs}$ at the cell surface as observed in several in vitro experiments, the absence of NCAM results in an increase of $\mathrm{D}_{2}$ Rs at the cell surface. On the other hand, the NCAM-mediated GDNF signaling is crucial for the survival of dopaminergic neurons (Lin et al., 1993; Paratcha et al., 2003), and, accordingly, the number of dopaminergic neurons is reduced in the substantia nigra of $\mathrm{NCAM}^{-1-}$ mice. Nevertheless, the reduced number of dopaminergic neurons does not alter total dopamine levels in the striatum of $\mathrm{NCAM}^{-1-}$ mice. However, we cannot exclude the possibility that extracellular dopamine levels may be reduced, which in turn could lead to a compensatory upregulation of $\mathrm{D}_{2} \mathrm{Rs}$ at the cell surface of $\mathrm{NCAM}^{-/-}$mice. Thus, it is conceivable that the increased number of $\mathrm{D}_{2} \mathrm{Rs}$ at the cell surface and the higher locomotor activity in $\mathrm{NCAM}^{-1-}$ mice is attributable to the direct regulatory effect of NCAM on $\mathrm{D}_{2} \mathrm{R}$ internalization, or indirect effect of NCAM on extracellular dopamine levels, or a combination of both effects.

Hyperactivity of dopamine receptors has been implicated in the pathogenesis of schizophrenia, and dysregulation of the agonist-induced internalization of $\mathrm{D}_{2}$ Rs was recently suggested to be responsible for this disorder (Iizuka et al., 2007). In the present study, we obtained indications that the interaction between NCAM and $\mathrm{D}_{2} \mathrm{R}$ is disturbed when $\mathrm{D}_{2} \mathrm{R}$ carries the Ser311Cys polymorphism found in schizophrenia patients (Itokawa et al., 1993). Thus, we speculate that, in schizophrenia, the internalization of $\mathrm{D}_{2} \mathrm{R}$ (S311C) is impaired because of its disturbed interaction with NCAM, which results in enhanced $\mathrm{D}_{2} \mathrm{R}$ signaling. Since a number of different studies suggest that alteration of the NCAM expression is linked to schizophrenialike phenotypes (Barbeau et al., 1995; van Kammen et al., 1998; Vawter et al., 1998), it is likely that dysregulation of NCAM expression leads to alterations in $\mathrm{D}_{2} \mathrm{R}$ internalization and $\mathrm{D}_{2} \mathrm{R}$ dependent signaling, and thus affects the $\mathrm{D}_{2} \mathrm{R}$-related neurological and emotional abnormalities in humans.

In conclusion, we identified a novel molecular mechanism by which $\mathrm{D}_{2} \mathrm{R}$ internalization and signaling and dopamine-related behavior is modulated by NCAM via direct cis-interaction in the postsynaptic plasma membrane (Fig. 8). NCAM deficiency increases the level of cell surface $\mathrm{D}_{2}$ Rs and enhances the $\mathrm{D}_{2} \mathrm{R}$ signaling, which in turn leads to hyperactivity of dopamine-related behavior. These observations provide a new alternative pathway 
by which the dopaminergic system is modulated. Investigations on the functions and mechanisms of this regulatory pathway in dopaminergic transmission should provide new insights into the understanding of neuropsychiatric disorders, thereby leading to novel views on therapeutic approaches.

\section{References}

Abi-Dargham A, Rodenhiser J, Printz D, Zea-Ponce Y, Gil R, Kegeles LS, Weiss R, Cooper TB, Mann JJ, Van Heertum RL, Gorman JM, Laruelle M (2000) Increased baseline occupancy of D2 receptors by dopamine in schizophrenia. Proc Natl Acad Sci U S A 97:8104-8109.

Barbeau D, Liang JJ, Robitalille Y, Quirion R, Srivastava LK (1995) Decreased expression of the embryonic form of the neural cell adhesion molecule in schizophrenic brains. Proc Natl Acad Sci U S A 92:27852789.

Bartlett SE, Enquist J, Hopf FW, Lee JH, Gladher F, Kharazia V, Waldhoer M, Mailliard WS, Armstrong R, Bonci A, Whistler JL (2005) Dopamine responsiveness is regulated by targeted sorting of D2 receptors. Proc Natl Acad Sci U S A 102:11521-11526.

Beaulieu JM, Sotnikova TD, Marion S, Lefkowitz RJ, Gainetdinov RR, Caron MG (2005) An Akt/beta-arrestin 2/PP2A signaling complex mediates dopaminergic neurotransmission and behavior. Cell 122:261-273.

Bohm SK, Grady EF, Bunnett NW (1997) Regulatory mechanisms that modulate signalling by G-protein-coupled receptors. Biochem J 322:1-18.

Brennaman LH, Maness PF (2008) NCAM in neuropsychiatric and neurodegenerative disorders. Neurochem Res. Advance online publication. Retrieved Oct. 18, 2009. doi:10.1007/s11064-008-9630-z.

Carlsson A (2001) A paradigm shift in brain research. Science 294: 1021-1024.

Chao CC, Ma YL, Chu KY, Lee EH (2003) Integrin alphav and NCAM mediate the effects of GDNF on DA neuron survival, outgrowth, DA turnover and motor activity in rats. Neurobiol Aging 24:105-116.

Chih B, Engelman H, Scheiffele P (2005) Control of excitatory and inhibitory synapse formation by neuroligins. Science 307:1324-1328.

Creese I, Burt DR, Snyder SH (1976) Dopamine receptor binding predicts clinical and pharmacological potencies of antischizophrenic drugs. Science 192:481-483.

Cremer H, Lange R, Christoph A, Plomann M, Vopper G, Roes J, Brown R, Baldwin S, Kraemer P, Scheff S, Barthels D, Rajewsky K, Wille W (1994) Inactivation of the N-CAM gene in mice results in size reduction of the olfactory bulb and deficits in spatial learning. Nature 367:455-459.

Diestel S, Schaefer D, Cremer H, Schmitz B (2007) NCAM is ubiquitylated, endocytosed and recycled in neurons. J Cell Sci 120:4035-4049.

Dodd J, Morton SB, Karagogeos D, Yamamoto M, Jessell TM (1988) Spatial regulation of axonal glycoprotein expression on subsets of embryonic spinal neurons. Neuron 1:105-116.

Edelman GM (1985) Cell adhesion molecule expression and the regulation of morphogenesis. Cold Spring Harb Symp Quant Biol 50:877-889.

Fux CM, Krug M, Dityatev A, Schuster T, Schachner M (2003) NCAM180 and glutamate receptor subtypes in potentiated spine synapses: an immunogold electron microscopic study. Mol Cell Neurosci 24:939-950.

Gainetdinov RR, Bohn LM, Sotnikova TD, Cyr M, Laakso A, Macrae AD, Torres GE, Kim KM, Lefkowitz RJ, Caron MG, Premont RT (2003) Dopaminergic supersensitivity in $G$ protein-coupled receptor kinase 6-deficient mice. Neuron 38:291-303.

Giros B, Sokoloff P, Martres MP, Riou JF, Emorine LJ, Schwartz JC (1989) Alternative splicing directs the expression of two D2 dopamine receptor isoforms. Nature 342:923-926.

Gray JA, Roth BL (2007) The pipeline and future of drug development in schizophrenia. Mol Psychiatry 12:904-922.

Greengard P (2001) The neurobiology of slow synaptic transmission. Science 294:1024-1030.

Hu XT, Wachtel SR, Galloway MP, White FJ (1990) Lesions of the nigrostriatal dopamine projection increase the inhibitory effects of $D_{1}$ and $D_{2}$ dopamine agonists on caudate-putamen neurons and relieve $\mathrm{D}_{2}$ receptors from the necessity of $D_{1}$ receptor stimulation. J Neurosci 10:2318-2329.

Hyman C, Hofer M, Barde YA, Juhasz M, Yancopoulos GD, Squinto SP, Lindsay RM (1991) BDNF is a neurotrophic factor for dopaminergic neurons of the substantia nigra. Nature 350:230-232.

Iizuka Y, Sei Y, Weinberger DR, Straub RE (2007) Evidence that the BLOC-1 protein dysbindin modulates dopamine $\mathrm{D}_{2}$ receptor internalization and signaling but not $\mathrm{D}_{1}$ internalization. J Neurosci 27:12390-12395.
Ito K, Haga T, Lameh J, Sadée W (1999) Sequestration of dopamine D2 receptors depends on coexpression of G-protein-coupled receptor kinases 2 or 5. Eur J Biochem 260:112-119.

Itokawa M, Arinami T, Futamura N, Hamaguchi H, Toru M (1993) A structural polymorphism of human dopamine D2 receptor, D2(Ser311 $\rightarrow$ Cys). Biochem Biophys Res Commun 196:1369-1375.

Itokawa M, Toru M, Ito K, Tsuga H, Kameyama K, Haga T, Arinami T, Hamaguchi H (1996) Sequestration of the short and long isoforms of dopamine D2 receptors expressed in Chinese hamster ovary cells. Mol Pharmacol 49:560-566.

Kabbani N, Levenson R (2007) A proteomic approach to receptor signaling: molecular mechanisms and therapeutic implications derived from discovery of the dopamine D2 receptor signalplex. Eur J Pharmacol 572: 83-93.

Kabbani N, Negyessy L, Lin R, Goldman-Rakic P, Levenson R (2002) Interaction with neuronal calcium sensor NCS-1 mediates desensitization of the $\mathrm{D}_{2}$ dopamine receptor. J Neurosci 22:8476-8486.

Kohsaka H, Takasu E, Nose A (2007) In vivo induction of postsynaptic molecular assembly by the cell adhesion molecule Fasciclin2. J Cell Biol 179:1289-1300.

Law JW, Lee AY, Sun M, Nikonenko AG, Chung SK, Dityatev A, Schachner M, Morellini F (2003) Decreased anxiety, altered place learning, and increased CA1 basal excitatory synaptic transmission in mice with conditional ablation of the neural cell adhesion molecule L1. J Neurosci 23:10419-10432.

Levivier M, Przedborski S, Bencsics C, Kang UJ (1995) Intrastriatal implantation of fibroblasts genetically engineered to produce brain-derived neurotrophic factor prevents degeneration of dopaminergic neurons in a rat model of Parkinson's disease. J Neurosci 15:7810-7820.

Li HL, Huang BS, Vishwasrao H, Sutedja N, Chen W, Jin I, Hawkins RD, Bailey CH, Kandel ER (2009) Dscam mediates remodeling of glutamate receptors in Aplysia during de novo and learning-related synapse formation. Neuron 61:527-540.

Lin LF, Doherty DH, Lile JD, Bektesh S, Collins F (1993) GDNF: a glial cell line-derived neurotrophic factor for midbrain dopaminergic neurons. Science 260:1130-1132.

Lindgren N, Usiello A, Goiny M, Haycock J, Erbs E, Greengard P, Hokfelt T, Borrelli E, Fisone G (2003) Distinct roles of dopamine D2L and D2S receptor isoforms in the regulation of protein phosphorylation at presynaptic and postsynaptic sites. Proc Natl Acad Sci U S A 100:4305-4309.

Liu Y, Buck DC, Macey TA, Lan H, Neve KA (2007) Evidence that calmodulin binding to the dopamine D2 receptor enhances receptor signaling. J Recept Signal Transduct Res 27:47-65.

Lyons F, Martin ML, Maguire C, Jackson A, Regan CM, Shelley RK (1988) The expression of an N-CAM serum fragment is positively correlated with severity of negative features in type II schizophrenia. Biol Psychiatry 23:769-775.

Maness PF, Schachner M (2007) Neural recognition molecules of the immunoglobulin superfamily: signaling transducers of axon guidance and neuronal migration. Nat Neurosci 10:19-26.

Missale C, Nash SR, Robinson SW, Jaber M, Caron MG (1998) Dopamine receptors: from structure to function. Physiol Rev 78:189-225.

Mousavi SA, Malerød L, Berg T, Kjeken R (2004) Clathrin-dependent endocytosis. Biochem J 377:1-16.

Muller D, Djebbara-Hannas Z, Jourdain P, Vutskits L, Durbec P, Rougon G, Kiss JZ (2000) Brain-derived neurotrophic factor restores long-term potentiation in polysialic acid-neural cell adhesion molecule-deficient hippocampus. Proc Natl Acad Sci U S A 97:4315-4320.

Namkung Y, Sibley DR (2004) Protein kinase C mediates phosphorylation, desensitization, and trafficking of the D2 dopamine receptor. J Biol Chem 279:49533-49541.

Nestler EJ (2001) Molecular basis of long-term plasticity underlying addiction. Nat Rev Neurosci 2:119-128.

Niethammer P, Delling M, Sytnyk V, Dityatev A, Fukami K, Schachner M (2002) Cosignaling of NCAM via lipid rafts and the FGF receptor is required for neuritogenesis. J Cell Biol 157:521-532.

Nuriya M, Huganir RL (2006) Regulation of AMPA receptor trafficking by N-cadherin. J Neurochem 97:652-661.

Paratcha G, Ledda F, Ibáñez CF (2003) The neural cell adhesion molecule NCAM is an alternative signaling receptor for GDNF family ligands. Cell 113:867-879.

Paspalas CD, Rakic P, Goldman-Rakic PS (2006) Internalization of D2 
dopamine receptors is clathrin-dependent and select to dendro-axonic appositions in primate prefrontal cortex. Eur J Neurosci 24:1395-1403.

Persohn E, Pollerberg GE, Schachner M (1989) Immunoelectron-microscopic localization of the $180 \mathrm{kD}$ component of the neural cell adhesion molecule N-CAM in postsynaptic membranes. J Comp Neurol 288: 92-100.

Pillai-Nair N, Panicker AK, Rodriguiz RM, Gilmore KL, Demyanenko GP, Huang JZ, Wetsel WC, Maness PF (2005) Neural cell adhesion molecule-secreting transgenic mice display abnormalities in GABAergic interneurons and alterations in behavior. J Neurosci 25:4659-4671.

Polo-Parada L, Bose CM, Landmesser LT (2001) Alterations in transmission, vesicle dynamics, and transmitter release machinery at NCAMdeficient neuromuscular junctions. Neuron 32:815-828.

Rankin ML, Marinec PS, Cabrera DM, Wang Z, Jose PA, Sibley DR (2006) The D1 dopamine receptor is constitutively phosphorylated by G proteincoupled receptor kinase 4. Mol Pharmacol 69:759-769.

Saglietti L, Dequidt C, Kamieniarz K, Rousset MC, Valnegri P, Thoumine O, Beretta F, Fagni L, Choquet D, Sala C, Sheng M, Passafaro M (2007) Extracellular interactions between GluR2 and N-cadherin in spine regulation. Neuron 54:461-477.

Schlosshauer B (1989) Purification of neuronal cell surface proteins and generation of epitope-specific monoclonal antibodies against cell adhesion molecules. J Neurochem 52:82-92.

Seeman P, Van Tol HH (1994) Dopamine receptor pharmacology. Trends Pharmacol Sci 15:264-270.

Siegel MR, Sisler HD (1963) Inhibition of protein synthesis in vitro by cycloheximide. Nature 200:675-676.

Stork O, Welzl H, Wotjak CT, Hoyer D, Delling M, Cremer H, Schachner M
(1999) Anxiety and increased 5-HT1A receptor response in NCAM null mutant mice. J Neurobiol 40:343-355.

Sun W, Ginovart N, Ko F, Seeman P, Kapur S (2003) In vivo evidence for dopamine-mediated internalization of D2-receptors after amphetamine: differential findings with $\left[{ }^{3} \mathrm{H}\right]$ raclopride versus $\left[{ }^{3} \mathrm{H}\right]$ spiperone. Mol Pharmacol 63:456-462.

Sytnyk V, Leshchyns'ka I, Nikonenko AG, Schachner M (2006) NCAM promotes assembly and activity-dependent remodeling of the postsynaptic signaling complex. J Cell Biol 174:1071-1085.

van Kammen DP, Poltorak M, Kelley ME, Yao JK, Gurklis JA, Peters JL, Hemperly JJ, Wright RD, Freed WJ (1998) Further studies of elevated cerebrospinal fluid neuronal cell adhesion molecule in schizophrenia. Biol Psychiatry 43:680-686.

Vawter MP, Cannon-Spoor HE, Hemperly JJ, Hyde TM, VanderPutten DM, Kleinman JE, Freed WJ (1998) Abnormal expression of cell recognition molecules in schizophrenia. Exp Neurol 149:424-432.

Wong DF, Wagner HN Jr, Tune LE, Dannals RF, Pearlson GD, Links JM, Tamminga CA, Broussolle EP, Ravert HT, Wilson AA, Toung JK, Malat J, Williams JA, O’Tuama LA, Snyder SH, Kuhar MJ, Gjedde A (1986) Positron emission tomography reveals elevated D2 dopamine receptors in drug-naive schizophrenics. Science 234:1558-1563.

Wood GK, Tomasiewicz H, Rutishauser U, Magnuson T, Quirion R, Rochford J, Srivastava LK (1998) NCAM-180 knockout mice display increased lateral ventricle size and reduced prepulse inhibition of startle. Neuroreport 9:461-466.

Zhou QY, Palmiter RD (1995) Dopamine-deficient mice are severely hypoactive, adipsic, and aphagic. Cell 83:1197-1209. 